\title{
Elevation changes and dynamic provinces of Jakobshavn Isbræ, Greenland, derived using generalized spatial surface roughness from ICESat GLAS and ATM data
}

\author{
Ute C. HERZFELD, ${ }^{1,2,3}$ Brian McDONALD, ${ }^{1,2}$ Bruce F. WALLIN, ${ }^{1}$ William KRABILL, ${ }^{4}$ \\ Serdar MANIZADE, ${ }^{4}$ John SONNTAG, ${ }^{4}$ Helmut MAYER, ${ }^{5}$ William Alex YEARSLEY, $, 1,3$ \\ Phillip A. CHEN ${ }^{1,2}$ Alexander WELTMAN ${ }^{1,6}$ \\ ${ }^{1}$ Department of Electrical, Computer and Energy Engineering, University of Colorado at Boulder, Boulder, CO, USA \\ E-mail: uch5678@gmail.com \\ ${ }^{2}$ Cooperative Institute for Research in Environmental Sciences, University of Colorado at Boulder, Boulder, CO, USA \\ ${ }^{3}$ Department of Applied Mathematics, University of Colorado at Boulder, Boulder, CO, USA \\ ${ }^{4}$ NASA Wallops Flight Facility, Wallops Island, VA, USA \\ ${ }^{5}$ Terra Mobilis, Lafayette, CO, USA \\ ${ }^{6}$ Department of Computer Sciences, University of Colorado at Boulder, Boulder, CO, USA.
}

\begin{abstract}
Our objective is to map dynamic provinces and investigate dynamic changes in Jakobshavn Isbræ, Greenland. We use an approach that combines structural glaciology and remote-sensing data analysis, facilitated by mathematical characterization of generalized spatial surface roughness that provides parameters related to ice dynamics, deformation and interaction of the ice with bed topography. The approach is applied to derive time series of elevation and roughness changes and to attribute changes during rapid retreat. Different dynamic types of fast- and slow-moving ice can be mapped from ICESat Geoscience Laser Altimeter System data (2003-09) and Airborne Topographic Mapper data, using spatial roughness characterization, validated with ASTER and bed-topographic data. Results of comparative analysis of elevation changes and roughness changes of Jakobshavn south ice stream indicate (1) surface lowering of 10-15 m a a $^{-1}$ between 2004 and 2009 and (2) no change in surface roughness and dynamic types. These findings are consistent with a front retreat as part of a fjord-glacier cycle or following warming of fjord water and with climatic warming, but not with an internal dynamic acceleration as a cause of the observed changes during rapid retreat. Relationships to changes in basal water pressure are discussed. All glaciodynamic changes appear to have initiated near the front and propagated up-glacier.
\end{abstract}

KEYWORDS: Arctic glaciology, crevasses, remote sensing, structural glaciology

\section{INTRODUCTION}

Jakobshavn Isbræ (Sermeq Kujalleq; Ilulissat Ice Stream) calves into Jakobshavn Isfjord (Ilulissat Isfjord; Kangia) at $\sim 69^{\circ} \mathrm{N}, 50^{\circ} \mathrm{W}$ in West Greenland. Jakobshavn Isbræ drains $6 \%$ of the Greenland ice sheet and has been known as the continuously fastest-moving glacier on Earth, moving at speeds of $20.6 \mathrm{~m} \mathrm{~d}^{-1}\left(7.5 \mathrm{~km} \mathrm{a}^{-1}\right)$ (Pelto and others, 1989) and $8.360 \mathrm{~km} \mathrm{a}^{-1}$ according to Echelmeyer and Harrison (1990) at the calving front. The glacier entered a phase of rapid retreat in 1999, which came to a halt in 2007 and continued in 2009 and 2010. The retreat has been accompanied by surface lowering and acceleration to about twice the previous velocity, modulated by a seasonal variability of slower winter speeds and thickening and faster summer speeds and increased thinning (Weidick, 1984; Pelto and others, 1989; Echelmeyer and Harrison, 1990; Echelmeyer and others, 1991, 1992; Iken and others, 1993; Krabill and others, 1999; Mayer and Herzfeld, 2000, 2001; Johnson and others, 2004; Joughin and others, 2004; Podlech and Weidick, 2004; Thomas, 2004; Thomas and others, 2004; Luckman and Murray, 2005; Joughin and others, 2008, 2010, 2012; Mayer and Herzfeld, 2008; Nick and others, 2009; Moon and others, 2012).
The objective of this paper is to investigate dynamic changes in Jakobshavn Isbræ, using an approach that combines structural glaciology and remote-sensing data analysis and is facilitated by mathematical characterization of generalized spatial surface roughness. Generalized spatial surface roughness is a mathematical concept that encompasses surface roughness and spatial structural properties of the ice surface, morphology and micro-morphology (short: surface roughness). This surface-roughness characterization serves to provide parameters that are related to ice flow, ice dynamics and interaction of the ice with bed topography.

The idea is to provide a method that facilitates mapping of geophysical parameters that relate to ice-dynamic change, using satellite and airborne altimeter data, and to apply this method to Jakobshavn Isbræ. First, we will demonstrate that the roughness approach can be applied to map dynamic provinces in fast and slow-moving ice and that several dynamic types can be distinguished. The focus of the paper is on ICESat (Ice Cloud and land Elevation Satellite) GLAS (Geoscience Laser Altimeter System) data analysis, and ATM (Airborne Topographic Mapper) data are included for high-resolution analysis and to validate GLAS data analysis. In addition, ASTER (Advanced Spaceborne 


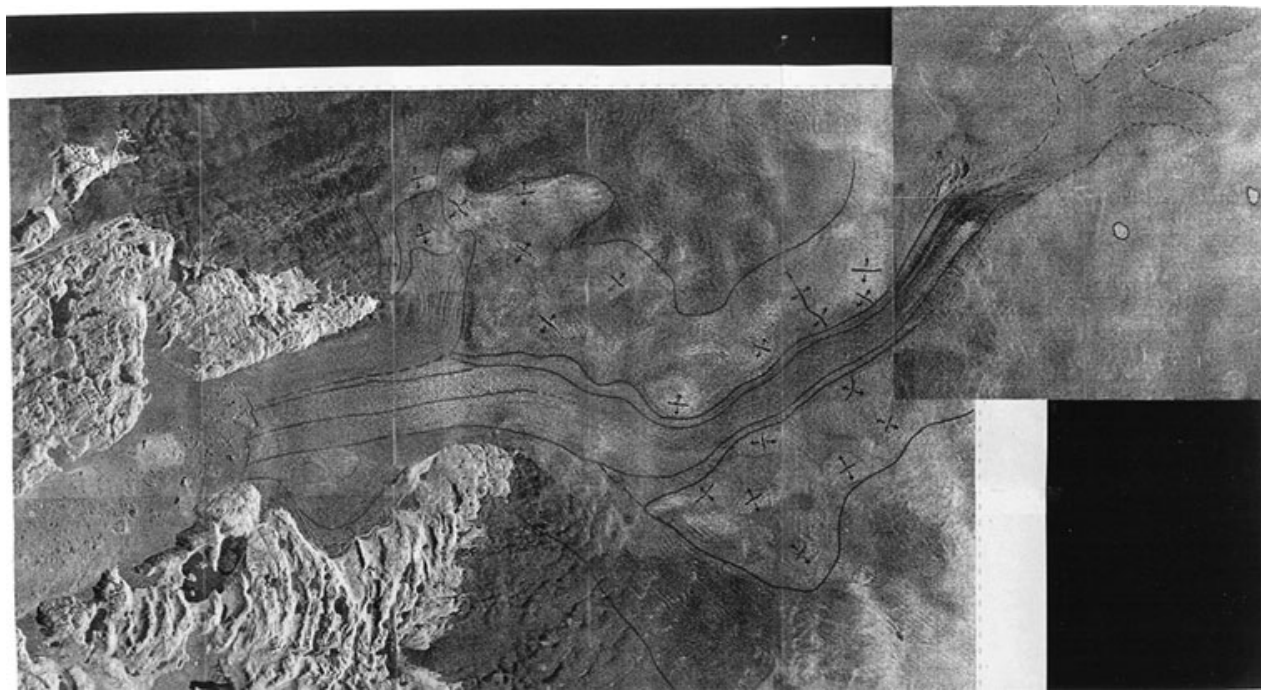

Fig. 1. Structural glaciological provinces of Jakobshavn Isbræ based on 1995 ERS-2 SAR data composition of (1) ERS-2 orbit 10958, descending frame 2205-25May1997 and (2) ERS-2 orbit 10915, descending frame 2205-22May1997 (data collected by European Space Agency). (From Mayer and Herzfeld 2001.) The main ice stream, marked here by double lines, is Jakobshavn south ice stream; the north ice stream joins the south ice stream north of the easternmost land promontory seen in this image. The center line of Jakobshavn south ice stream is indicated in the lower part of the ice stream. The symbols indicate directions of extension.

Thermal Emission and Reflection Radiometer) data of the NASA Terra satellite are used for validation.

Second, the approach will then be applied to investigate elevation and roughness changes in Jakobshavn Isbræ south ice stream during rapid retreat, which occurred between 1999 and 2007, to contribute to solving the Jakobshavn problem: what is the cause of this rapid retreat? Possible causes of the observed changes include: (1) a fjord-glacier cycle (Meier and Post, 1987; Pfeffer, 2007; Vieli and Nick, 2011), (2) calving of the front and acceleration started in consequence of climatic warming in the Jakobshavn glacier region (Box and Steffen, 2001; Steffen and Box, 2001; Box and others, 2009), (3) acceleration due to an internal change in the glacier's dynamic system, and (4) increased calving and front retreat due to warming of the water in Ilulissat Isfjord, which then led to upward propagation of acceleration due to lack of back-holding force (Rignot and others, 2012; Straneo and others, 2012; cf. Truffer and Echelmeyer, 2003). Jakobshavn Isbræ is arguably the best-studied tidewater glacier on Earth, yet its recent retreat has not been fully attributed to any one of these possible causes, or to a combination.

\section{APPROACH}

The approach used here combines structural glaciology and analysis of generalized surface roughness. The principal concept is that the dynamics of fast-moving ice manifest themselves in crevassing, and consequently the deformation history of the ice can be reconstructed by analysis of crevasse patterns. Structural geologic principles provide links between dynamics, kinematics and deformation, which can be physically formalized and quantified using continuum mechanics (Means, 1976; Suppe, 1985; Twiss and Moores, 1992; Ramsay and Lisle, 2000; Liu, 2002; Greve, 2003). Crevassing is a form of brittle deformation that occurs when local forces exceed a threshold. Characterization of generalized spatial surface roughness is a mathematical approach that utilizes parameters derived from spatial statistical functions to capture spatial properties of a surface (Herzfeld,
2008). This applies to crevassed and non-crevassed ice surfaces. Combining structural geology and mathematical roughness analysis allows us to derive deformation characteristics in fast-moving glaciers, as described in theory in Herzfeld and others (2004), and to map deformation provinces in surging and continuously fast-moving glaciers (Herzfeld and Mayer, 1997; Herzfeld 1998, 2008; Herzfeld and others, 2000; Mayer and Herzfeld, 2000, 2001; Herzfeld and Zahner, 2001; Herzfeld, 2008; cf. Vornberger and Whillans, 1990; Marmo and Wilson, 1998; Rist and others, 1999). Hence crevasse patterns and surface roughness can be used as a source of geophysical or glaciological information. For mapping and monitoring of dynamic changes in fast-flowing glaciers and ice streams in Greenland, Antarctica and other remote areas, it will be useful to be able to perform this from space. In this paper, we investigate to what extent ice surface roughness affects satellite and airborne laser altimeter data and, in turn, to what extent roughness characteristics derived from laser altimeter data can be employed to map dynamic provinces. The area of Jakobshavn Isbræ and its neighborhood provides a good test area for this approach, because many different crevasse types and roughness types are encountered in the fast-moving glacier and the adjacent slow-moving ice.

Two types of laser altimeter data are used: GLAS data collected during the ICESat mission (2003-09) (Schutz and others, 2005; Zwally and others, 2005) and ATM data collected from NASA aircraft (Krabill and others, 1995). The ICESat ground tracks cross the fast-moving Jakobshavn Isbræ south ice stream at angles that sample the ice stream's dynamical provinces almost perfectly, as will be derived below. ATM data that were simultaneously collected underflying ICESat in March 2006 and March 2007 will be employed to validate the GLAS data analysis and provide higher-resolution information.

Applications are (1) mapping ice-dynamic provinces or types in Jakobshavn Isbræ and its environs, (2) analysis of changes in elevation and surface roughness and (3) glaciological interpretation. 

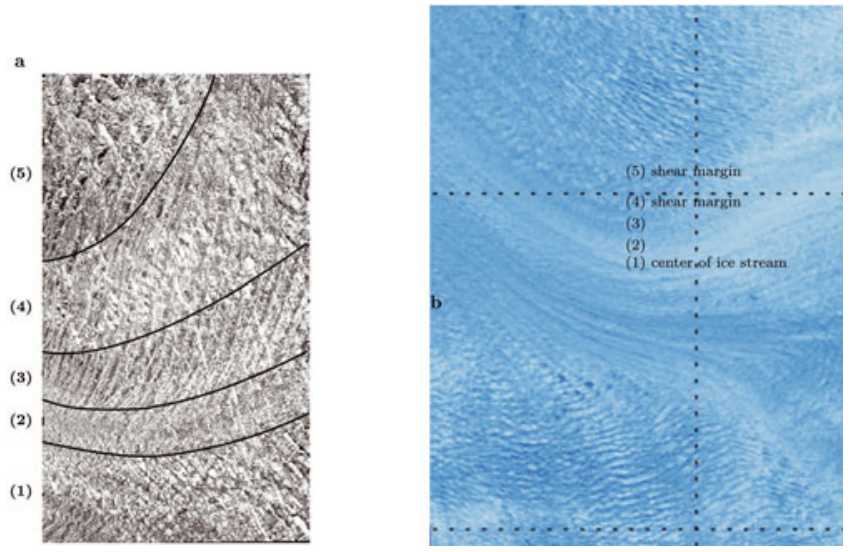

Fig. 2. Longitudinal zonation of the focused core of Jakobshavn Isbræ south ice stream, 1996 and 2003. (a) Based on 1996 aerial photograph. From center (left) to margin (right), view in flow direction: (1) closed compressional and conjugate shear faults, (2) very smooth surface with pervasive shear deformation, (3) closed conjugate shear faults with one dominant direction curving into flow direction towards center, (4) closed conjugate shear faults, (5) slightly open extensional crevasses in multiple directions. Zones repeat symmetrically on the other side of the center line. (After Mayer and Herzfeld, 2001, fig. 5.) Photograph taken slightly downstream of the turn in the south ice stream. (b) Same zones indicated on top of 2003 Terra ASTER image (see Fig. 3); crossing of 1996 flight line is just to the left of the numbers. The zone names 'shear margin' and 'center of ice stream' have been added for general reference. Comparison of (a) and (b) shows that dynamic provinces have not changed.

\section{DYNAMIC PROVINCES OF JAKOBSHAVN ISBRA DETERMINED USING STRUCTURAL GLACIOLOGY}

An overview of the dynamic provinces of Jakobshavn Isbræ is given in Figure 1, based on synthetic aperture radar (SAR) data collected with the European Remote-sensing Satellite ERS-2 on 22 and 25 May 1997 (Mayer and Herzfeld, 2001). The analysis shown in Figure 1 uses a composition of two ERS-2 datasets: ERS-2 orbit 10958, descending frame 220525May1997; and ERS-2 orbit 10915, descending frame 2205-22May1997.

A close-up of the fast-moving south ice stream allows a finer classification into five different crevasse classes, which are oriented parallel to the center line and occur symmetrical to the center line: (1) closed compressional and conjugate shear faults, (2) very smooth surface with pervasive shear deformation, (3) closed conjugate shear faults with one dominant direction curving into flow direction towards the center, (4) closed conjugate shear faults and (5) slightly open extensional crevasses in multiple directions (Fig. 2a). Zone (1) in Figure 2 contains the center line (marked in Fig. 1), and zone 5 is the shear margin, located outside the double lines that mark the fast-moving Jakobshavn south ice stream. A comparison with an ASTER image of the NASA Terra satellite, taken in May 2003, shows that the longitudinal zones of Jakobshavn south ice stream had remained structurally unchanged (Fig. 2b). Aerial photographic observations collected in 2005 indicated that the longitudinal zones of the south ice stream continued to stay the same (Mayer and Herzfeld, 2008). Large melt ponds remained throughout the decade 1995-2005, but the number of small melt ponds increased.

The structural glaciological provinces of Jakobshavn Isbræ south ice stream are longitudinally aligned centered around the flowline, because Jakobshavn Isbræ follows a subglacial trough, which runs generally west-east (see Fig. 1 and compare with Figs 3 and 4 and analysis in Section 6). The trough causes the acceleration from slow-moving inland ice to fast-moving ice stream. Therefore, the first and seventh authors flew the 1996 observation tracks in directions normal to the ice stream's flowline to sample surface properties of the structural provinces. Figure 2 documents these. ICESat GLAS tracks happen to be oriented and located almost perfectly to analyze spatial roughness characteristics of these longitudinally oriented provinces, because the tracks run approximately north-south, with the ascending and descending tracks forming a narrow angle. The track selected in Figure 4 crosses the south ice stream just down-glacier of the bend and thus is located close to one of our 1996 flight tracks and was underflown with the ATM instrument in March 2005 and March 2006. The coincidence of these three datasets facilitates the analysis in this paper.

\section{MATHEMATICAL BACKGROUND: GEOSTATISTICAL CLASSIFICATION BASED ON ICESat GLAS AND ATM ALTIMETER DATA}

The analysis in this paper applies the geostatistical characterization and classification method as introduced in Herzfeld $(2002,2008)$. In the interest of brevity, we limit the mathematical description to the functions and parameters employed here. A mathematical treatment and comparative analysis of generalized roughness analysis for laser altimeter data, especially ICESat GLAS data, using waveform parameters and geostatistical classification parameters is deferred to a later paper. To mathematically summarize spatial surface roughness in a given area, a vario function is formed. In this paper we use the first-order vario function and the residual vario function, motivated and defined as follows (Eqn (1)). If we are interested in characterizing the surface structure in a given area, then the actual value of surface elevation at each location is not as relevant as the parameters that describe the morphology more generally for the whole study area. Therefore, we form differences of measurement values and average over all points that have the same common distance (or distance and direction), creating vario functions, defined by

$$
v_{1}(h)=\frac{1}{2 n} \sum_{i=1}^{n}\left[z\left(x_{i}\right)-z\left(x_{i}+h\right)\right]^{2}
$$

for pairs of points $\left(x_{i}, z\left(x_{i}\right)\right),\left(x_{i}+h, z\left(x_{i}+h\right)\right) \in \mathcal{D}$, where $\mathcal{D}$ is a region in $\mathcal{R}^{2}$ (case of survey profiles) or $\mathcal{R}^{3}$ (case of survey areas) and $n$ is the number of pairs separated by $h$; the distance value $h$ is also termed lag. The function $v_{1}(h)$ is called the first-order vario function. This function exists always and has a finite value, because only finitely many data points enter the calculation. In situations where a regional trend or a local drift underlies the data, the residual vario function is often more useful to analyze roughness. With

$$
m(h)=\frac{1}{n} \sum_{i=1}^{n}\left[z\left(x_{i}\right)-z\left(x_{i}+h\right)\right]
$$

the residual vario function is defined as:

$$
\operatorname{res}_{1}(h)=v_{1}(h)-\frac{1}{2} m(h)^{2}
$$

If average surface elevation is constant for distance lag $h$, then $m(h)=0$ and $\operatorname{res}_{1}(h)=v_{1}(h)$, and if the surface is 

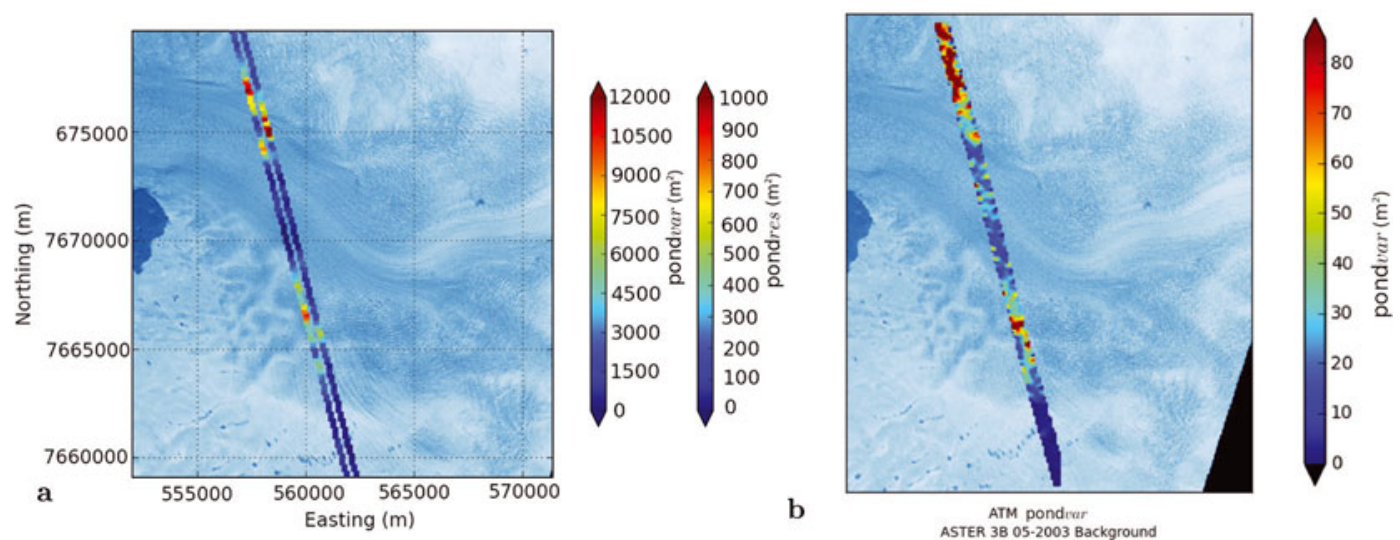

Fig. 3. Generalized roughness measures for Jakobshavn Isbræ south derived from ICESat GLAS data and ATM data. (a) Geostatistical pond ${ }_{\text {var }}$ and pond $_{\text {res }}$ parameters allow us to map ice-dynamic roughness provinces of Jakobshavn Isbræ's south ice stream. GLAS L3I data, November 2007. From left to right: geostatistical classification parameters pond $d_{\text {var }}$, pond $_{\text {res. }}$. Tracks offset to show different parameters; left track is in true location. UTM coordinates. (b) Ice-surface roughness mapped from full-resolution ATM data using geostatistical pond ${ }_{\text {var }}$ parameter indicates ice-dynamic provinces of Jakobshavn Isbræ's south ice stream. 2009 IceBridge ATM data. (a, b) Background ASTER data May 2003, NASA Terra satellite.

stationary in the statistical sense, then $r e s_{1} \equiv v_{1}$. The latter is heuristically not the case for glaciers and ice streams, therefore use of the residual vario function is often more appropriate.

The pond parameter is defined as the maximal value of the vario function. The higher the spatial variability, the higher is the pond value. In our application, the vario function is evaluated for a moving window along GLAS or ATM tracks, using a maximum lag distance of 0.8 times the window length, then the pond parameter is the maximum of the vario-function values in that window. The terms pond ${ }_{\text {var }}$ and pond $_{\text {res }}$ designate pond determined from the first-order vario function $v_{1}$ and the residual vario function res $_{1}$, respectively. For ice regions with approximately constant average height (e.g. some sub-areas of the Greenland inland ice), the pond $d_{\text {var }}$ parameter may be better suited, whereas for areas with sloping topography (e.g. drainage basins of outlet glaciers), the pond $d_{\text {res }}$ may be more appropriate. We examine this further in Sections 6 and 9.

\section{INSTRUMENTATION AND DATA: ICESat GLAS AND ATM}

The GLAS instrument aboard ICESat is a pulse-limited laser altimeter operated at $40 \mathrm{~Hz}, 532 \mathrm{~nm}$ and $1064 \mathrm{~nm}$ using a doubler crystal. The $1064 \mathrm{~nm}$ (infrared) laser channel is designed for measurements of surface altimetry and heights of dense clouds, and the $532 \mathrm{~nm}$ (green) lidar channel for measurements of the vertical distribution of clouds and aerosols. Altimeter data are derived using waveform fitting of the returned signal, geolocation and inversion of two-way travel time for range determination. With the help of precise orbit determination, laser-pointing correction and several other corrections, elevation of the ice surface is calculated (Schutz and others, 2005; Herzfeld and others, 2008). All satellite altimeter data follow ground tracks with points $(65 \mathrm{~m}$ diameter footprints for GLAS) spaced along-track (172 $\mathrm{m}$ for GLAS) and large gaps in between, with spacing dependent on latitude. For most of the ICESat mission, a 33 day subcycle of a 91 day repeat orbit was used. Following failure of the first of the lasers (labeled L1, L2, L3) early in the mission, a 33 day observation cycle was carried out three times per year
(February or March, May, October-November), and later twice per year (February or March and October-November). Track spacing at $70^{\circ}$ latitude is $10.1 \mathrm{~km}$ for the designed 91 day orbit and $29.7 \mathrm{~km}$ for the actual 33 day subcycle of the 91 day repeat orbit. Note that, other than a radar altimeter, the laser altimeter signal does not penetrate optically dense clouds (but thin clouds); this results in significant losses of surface returns, especially in the Arctic (Spinhirne and others, 2005).

Small variabilities exist in the ground-track locations for the repeat tracks, and along-track locations of points also vary between the 33 day missions. Elevation and pond difference values for data from two different tracks are only formed if pairs of points are found in a small window with a small tolerance. This reduces the effects of slopes (in any direction) especially on the elevation differences and differences in pond $_{\text {var; }}$ parameter pond $d_{\text {res }}$ is not affected by surface slope.

The ATM, in contrast, uses a scanning laser technique, which results in $\sim 10000$ points per near-circular ellipsoidal scan (Krabill and others, 1995). Because the aircraft carrying the laser moves forward, the ground pattern of observation is a spiral. Points are spaced 3-4 $\mathrm{m}$ apart at near-nadir locations and 5-6 $\mathrm{m}$ apart along the outer margins of the swath. Our analysis uses full-resolution data. Application of the classification method requires prior aggregation of data into location-referenced bins.

\section{ROUGHNESS AND DYNAMIC PROVINCES OF JAKOBSHAVN ISBRA FROM GLAS AND ATM DATA}

${\text { Geostatistical classification parameters } \text { pond }_{\text {var }} \text { and pond }}_{\text {res }}$ are calculated for ICESat GLAS data of all missions, using along-track moving windows, and for the much finer ATM data. The result is shown in Figure 3a for GLAS L3I data (November 2007) and in Figure 3b for ATM data (2009), superimposed on a color composite of the high-resolution ( $15 \mathrm{~m}$ pixel) bands $1,2,3$ of ASTER data from the Terra satellite. The ASTER data show the dynamic provinces in the Jakobshavn region, such as the central fast-moving south ice stream, the wide shear margins north and south of that, undulating ice surface and smooth ice with melt ponds in the southern part of the area in Figure $3 \mathrm{a}$, and large crevasses that 


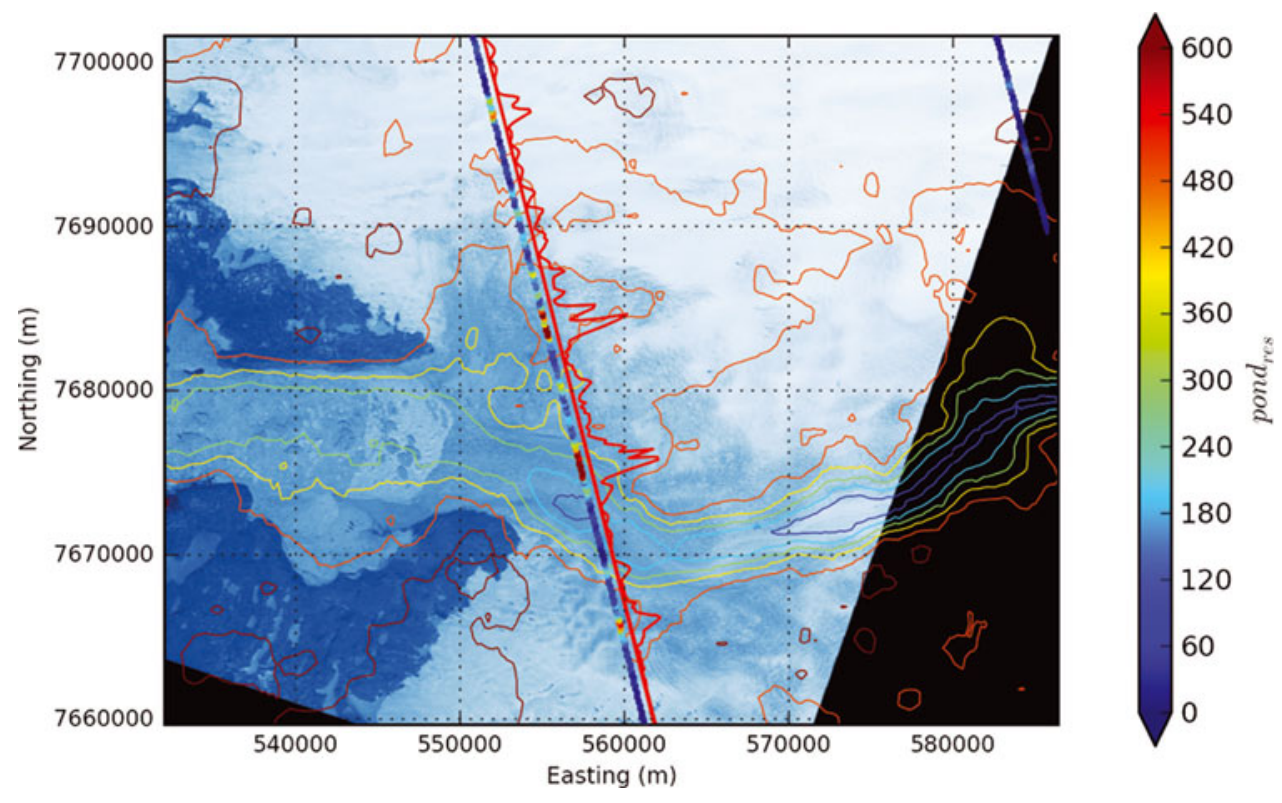

Fig. 4. Ice-surface roughness from GLAS data, subglacial topography from CReSIS MCoRDS data and crevassing and surface image from Terra ASTER data for Jakobshavn Isbræ region. GLAS L3I data from November 2007; roughness measure pond ${ }_{\text {res. }}$. Subglacial topography regridded and contoured from CReSIS MCoRDS data. Background ASTER data May 2003. UTM coordinates. Value of pond res parameter plotted normally to flight track (red) demonstrates relationship to crevasse provinces and subglacial topography.

cause disintegration of the lower Jakobshavn Isbræ. The spatial distribution of values of the pond $_{\text {var }}$ parameter matches the location of the ice-dynamic provinces. The same is true for the pond $_{\text {res }}$ parameter, but values are generally lower, because the residual with respect to the drift is formed (Eqn (3)). Highest values occur over the heavily crevassed shear zones north and south of the south ice stream. A comparison of Figures $3 \mathrm{a}$ and 2 shows that of the five longitudinal crevasse zones identified in photographs, the central one (zone 1) and the neighboring, smoothest zone 2 with closed crevasses are resolved in the ASTER data near the bend in the south ice stream $(564000 \mathrm{~W}$, $7671000 \mathrm{~N})$. Zones 3 and 4 appear similar, and the shear margin is clearly visible. At the location where the GLAS track crosses, the focused core does not show zones 1 and 2 separately (cf. Fig. 2b). The pond $d_{\text {var }}$ and pond ${ }_{\text {res }}$ values from GLAS data do not resolve the longitudinal bands in the central core, but the transverse increase in roughness from the center out is well resolved. The analysis is of course limited by the resolution of the data.

Application of the classification parameters to the much finer ATM data (Fig. 3b) reflects that the fast-moving ice stream is smoothest in longitudinal bands to the side of the center and then increases in several steps towards the shear margin, where highest pond $d_{\text {var }}$ values are derived. The region south of the southern shear margin shows the overall lowest roughness values; this is an area of uncrevassed ice with melt ponds.

\section{ICE-SURFACE ROUGHNESS AND SUBGLACIAL TOPOGRAPHY}

Attribution of acceleration in ice streams and resultant crevassing generally falls into two categories, dynamically and topographically induced. Many outlet glaciers of the Greenland ice sheet follow troughs in the bedrock, evident in surface roughness as mappable by the above-mentioned parameters from GLAS altimeter data.
The fast glacier flow in Jakobshavn Isbræ south ice stream is caused by a subglacial trough. The combined effects of convergent flow of ice into the trough and increased basal sliding (due to thicker ice and hence higher pressure at the base of the trough) lead to spatially accelerated flow of the ice stream, and the faster flow causes heavy crevassing. In order to analyze the spatial relationships between subglacial bed topography, ice-surface roughness and crevassing, we reanalyzed bed topographic data and created a highresolution map, co-referenced with the ASTER and ICESat satellite data (Fig. 4). The bed-topographic data were collected by the Center for Remote Sensing of Ice Sheets (CReSIS), University of Kansas, USA, using the Multichannel Coherent Radar Depth Sounder (MCoRDS) (Gogineni and others, 2001; Lohoefener, 2006; Li, 2009). Figure 4 shows bed topography, crevassing from 2003 ASTER data and surface roughness from GLAS data (2007), quantified by the pond $_{\text {res }}$ parameter. Figure 4 demonstrates that the fast ice movement of Jakobshavn Isbræ south ice stream, which is indicated by heavy crevassing that extends $>80 \mathrm{~km}$ into the ice sheet, follows the location of a subglacial trough. The composite of radar data, image data and roughness parameters provides evidence that the spatial acceleration of Jakobshavn Isbræ is caused by the presence of the trough, which is not the case for the north ice stream. Spatial surface roughness properties calculated from GLAS data allow us to more closely relate spatial acceleration of the ice to dynamic provinces, as analyzed in more detail in Section 6. While highest velocities are known to occur in the center of the ice stream, the roughest terrain is found in the shear margins of the south ice stream and in the area where the north ice stream accelerates. Overall, the fast-moving ice stream has higher surface roughness than the surrounding inland ice, which moves at $0.3 \mathrm{ma}^{-1}$. Highest roughness values occurring over the shear margins are related to the spatial velocity gradient. The fastest-moving center of the ice stream lines up with the center of the trough and has an intermediate roughness. The inner edge of the shear margins 

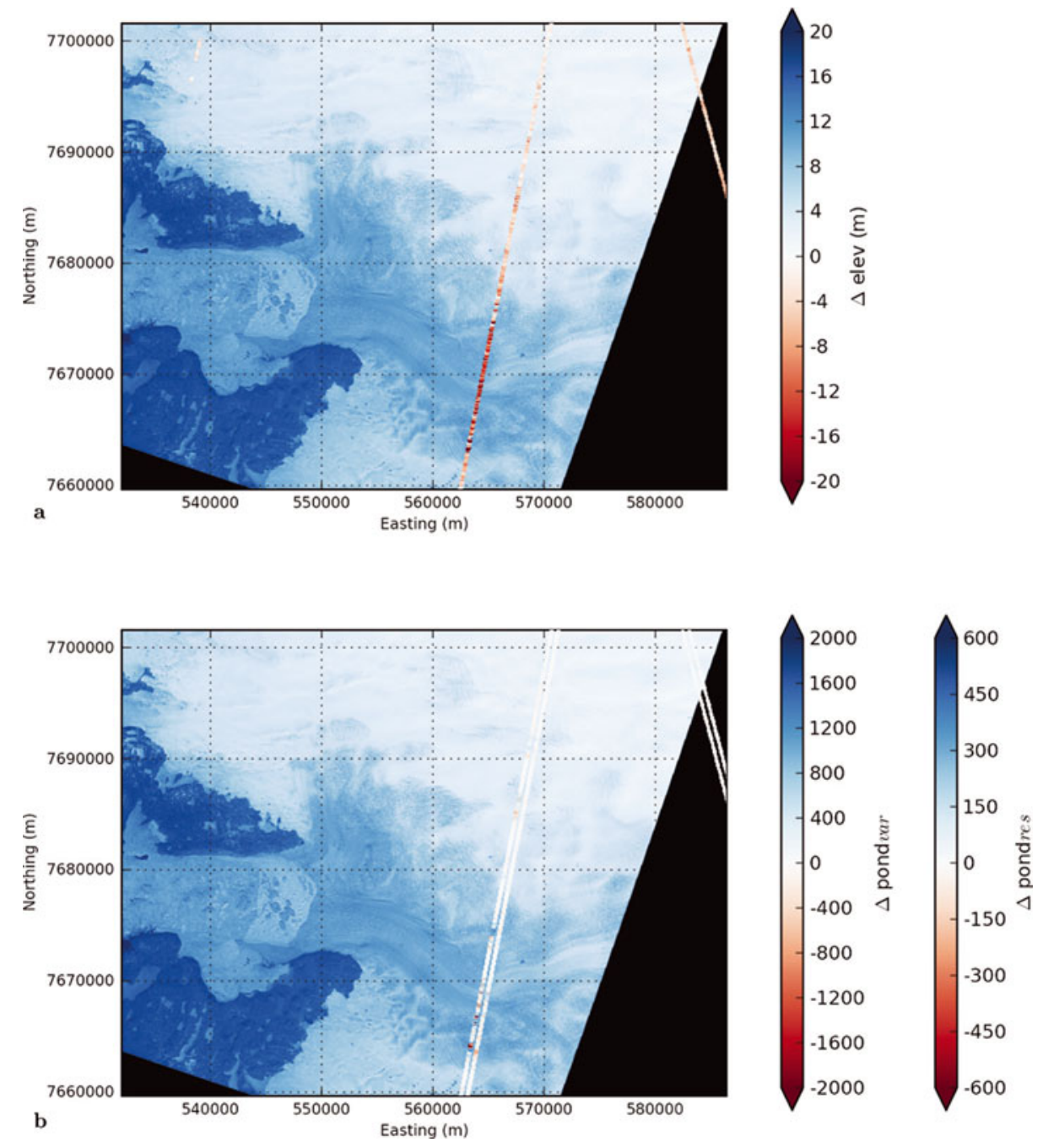

Fig. 5. Jakobshavn Isbræ south surface lowering and surface roughness changes between March 2006 (GLAS L3E) and March 2007 (GLAS $\mathrm{L} 3 \mathrm{H}$ ). (a) Surface lowering rate was $\sim 15 \mathrm{~m} \mathrm{a}^{-1}$, varying locally to $20 \mathrm{~m} \mathrm{a}^{-1}$. (b) Surface roughness changes, calculated as differences in parameters pond $_{\text {var }}$ (left) and pond $d_{\text {res }}$ (right) between March 2006 (GLAS L3E) and March 2007 (GLAS L3H). Results for pond res $_{\text {offset to the right }}$ for visualization purposes; correct location of the track is that of the left track. (a, b) Background ASTER data May 2003, NASA Terra satellite.

coincides in location with the outer edge of the subglacial trough in the CReSIS data.

Surface processes such as wind and melting also influence generalized spatial ice surface roughness, but occur on a smaller spatial scale than crevassing, to $\sim 10 \mathrm{~m}$, and are morphologically less significant, resulting in much ${\text { smaller } \text { pond }_{\text {var }} \text { and pond }}_{\text {res }}$ parameters outside crevassed areas (Figs 3 and 4; Herzfeld and others, 1999, 2000). In crevassed regions such as the lower reaches of Jakobshavn Isbræ and other fast-flowing Greenland outlet glaciers, ice dynamics is the main source of surface roughness.

\section{CHANGE IN ELEVATION IN JAKOBSHAVN SOUTH ICE STREAM}

Since 1999 Jakobshavn Isbræ has exhibited a rapid retreat of the ice front and surface lowering. A goal of this paper is to contribute to analyzing and understanding these changes. We apply the methods described in the previous sections and investigate the variables (1) elevation change, (2) change in surface roughness as quantified by the pond parameters, and (3) subglacial topography. For clarity, the analysis is first carried out for two points in time (March 2006 and March 2007; for exact mission intervals see
Table 1) during rapid retreat and surface lowering of Jakobshavn Isbræ. The analysis of change detection is based on ICESat GLAS data from March 2006 (GLAS L3E) and March 2007 (GLAS L3H). These two mission time frames were selected because data are available for the same season and the same track locations and data density along-track is very good, which allows a comparative analysis. In Section 10 the analysis will be extended to time series.

Differences between March 2007 and November 2006 altimeter data indicate a surface lowering of $10-20 \mathrm{~m}$ in 1 year over the south ice stream (Fig. 5a). The highest values occur at the center of the south ice stream. Elevation differences gradually decrease over the northern shear zone to lower values of $\sim 4 \mathrm{~m}$ in the slow-moving ice area north of Jakobshavn Isbræ south ice stream. Elevation difference values also decrease to the south of the south ice stream, with a high variability over the southern shear margin. Local variability may be attributed to a forward-scattering effect or multiple returns over crevassed areas. However, all elevation difference values are negative. Considering that spatial variability in elevation change is likely due to crevassing, the amount of surface lowering generally increases toward the center of the south ice stream. 
Table 1. ICESat GLAS missions. ID refers to identity of the laser (L1, L2 or L3) and the operation time frame. Date format is yyyy-mm-dd

\begin{tabular}{lcc} 
ID & Temporal coverage & Orbit \\
\hline 1A & $2003-02-20$ to 2003-03-21 & 8 day \\
1B & $2003-03-21$ to 2003-03-29 & 8 day \\
2A & $2003-09-25$ to 2003-10-04 & 8 day \\
2A & $2003-10-04$ to 2003-11-19 & 91 day \\
2B & $2004-02-17$ to 2004-03-21 & 91 day \\
2C & $2004-05-18$ to 2004-06-21 & 91 day \\
3A & $2004-10-03$ to 2004-11-08 & 91 day \\
3B & $2005-02-17$ to 2005-03-24 & 91 day \\
3C & $2005-05-20$ to 2005-06-23 & 91 day \\
3D & $2005-10-21$ to 2005-11-24 & 91 day \\
3E & $2006-02-22$ to 2006-03-28 & 91 day \\
3F & $2006-05-24$ to 2006-06-26 & 91 day \\
3G & $2006-10-25$ to 2006-11-27 & 91 day \\
3H & $2007-03-12$ to 2007-04-14 & 91 day \\
3I & $2007-10-02$ to 2007-11-05 & 91 day \\
3J & $2008-02-17$ to 2008-03-21 & 91 day \\
3K & $2008-10-04$ to 2008-10-19 & 91 day \\
2D & $2008-11-25$ to 2008-12-17 & 91 day \\
2E & $2009-03-09$ to 2009-04-11 & 91 day \\
2F & $2009-09-30$ to 2009-10-11 & 91 day \\
\hline
\end{tabular}

\section{CHANGES IN ROUGHNESS IN JAKOBSHAVN SOUTH ICE STREAM}

Changes in surface roughness in the same time frame of March 2006 (GLAS L3E) to March 2007 (GLAS L3H) are shown in Figure 5b. Surface-roughness change in time is calculated as

$$
\begin{aligned}
& \Delta \text { pond }_{\mathrm{var}}=\text { pond }_{\mathrm{var}}\left(t_{2}\right)-\text { pond }_{\mathrm{var}}\left(t_{1}\right) \\
& \Delta \text { pond }_{\mathrm{res}}=\text { pond }_{\mathrm{res}}\left(t_{2}\right)-\text { pond }_{\mathrm{res}}\left(t_{1}\right)
\end{aligned}
$$

for two points in time $t_{1}, t_{2}$. Surface-roughness changes as

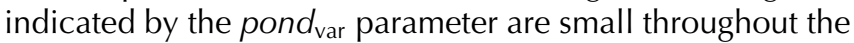
study area. However, pond $d_{\text {var }}$ shows variability especially in areas of crevasse fields that may be associated with undulations in surface topography and with the sloping margins of the south ice stream (the ice stream is lower than the surrounding inland ice; see Section 10). As expected from Eqns (2) and (3), the values of pond ${ }_{\text {var }}$ are affected by the local trend of the underlying topography. The fact that the local trend is nonzero is also visible in the fact that pond $_{\text {var }}$ and pond $d_{\text {res }}$ are locally different (Fig. 3). Hence the pond $_{\text {res }}$ parameter is used in the following analysis of roughness changes. Spatial variability is very low for pond $_{\text {res. }}$ In conclusion, during the time of rapid elevation drop, the spatial and temporal distribution of the roughness provinces did not change. The implications of this observation are discussed in Section 11.

\section{TIME SERIES OF ELEVATION CHANGES AND ROUGHNESS CHANGES}

The objective of this section is to investigate elevation and roughness changes over several years. The ICESat mission lasted from 2003 to 2009, but it is difficult to find time frames with data that are useful for comparison. Limiting factors are the following: Data were collected only for two to three 33 day intervals per year, termed missions (Table 1).
While the basic ground track pattern was repeated in each of those operation times, off-pointing manoeuvres in the area of lower Jakobshavn Isbræ limit the coincidence of tracks in the same locations. Furthermore, lidar data are generally affected by dense cloud cover, which further limits the number of comparisons between tracks that can be used for change detection by along-track data evaluation (Spinhirne and others, 2005). For the purpose of this paper, we have analyzed all GLAS data collected in the study area during the entire ICESat time frame 2003-09 and formed elevation and roughness differences for all possible pairs of missions (Table 1). Pairs of GLAS data that yielded sufficiently many points are investigated in the sequel.

Data from missions $\mathrm{L} 3 \mathrm{H}$ and $\mathrm{L} 3 \mathrm{E}$ were selected as primaries, because footprints for these two tracks match well in location, and hence elevation and roughness differences can be calculated for an entire across-flow profile. To observe the retreat of Jakobshavn Isbræ, off-pointing manoeuvres of tracks whose original position was near the front of the glacier to the front of the ice stream were frequently undertaken; this yields the differences in location between the tracks that cross the lower ice stream (track 1 is in location $1 \mathrm{a}$ or $1 \mathrm{~b}$ ) in Figure 6 and is also the reason that the track seen at ( $E$ 563000/ N 7660000) to (E 553000/ $\mathrm{N} 7700000)$ in Figure 6b appears to be missing in Figure 5. We use the names track $1 \mathrm{~A}$ for the track at (E 555000/ $\mathrm{N} 7660000$ ) to (E 545000/ N 7700000) in Figure 6a, track 1B for the track at (E 563000/ N 7660000) to (E 553000/ $\mathrm{N} 7700000)$ in Figure $6 \mathrm{~b}$ and track 2 for the track that is common to $\mathrm{L} 3 \mathrm{H}$ and $\mathrm{L} 3 \mathrm{E}$ and crosses the center of Jakobshavn south ice stream near its southernmost point (Figs 5, 6a and $\mathrm{b}$ and $7 \mathrm{a}$ and $\mathrm{b}$ ).

Figure 6 shows surface elevation change rates in map view, given as elevation change per year with rates accurate to the number of months. Figure 6a shows surface elevation change per year relative to March 2006 (L3E), and Figure 6b the same relative to March 2007 (GLAS L3H). Elevations for L3B, L3C, L3D, L3H, L2E were subtracted from elevations for $\mathrm{L} 3 \mathrm{E}$, and elevations for $\mathrm{L} 2 \mathrm{~B}, \mathrm{~L} 3 \mathrm{D}, \mathrm{L} 3 \mathrm{E}, \mathrm{L} 3 \mathrm{I}, \mathrm{L} 3$ J were subtracted from elevations for $\mathrm{L} 3 \mathrm{H}$. The elevation differences were divided by the time (months/12) between the two missions in the pair. Elevation differences were only formed if matching elevation points were found in two tracks, with a small tolerance in location of the points. This avoids matching points across large differences in location, where slope effects in any direction might bias an elevation difference. Surface lowering is observed not only during the year March 2006-March 2007 (Fig. 5), but occurred monotonously throughout the observation time frame at rates of $10-15 \mathrm{~m} \mathrm{a}^{-1}$. For the tracks that cross the south ice stream near its bend (tracks 1B and 2), elevation losses are largest over the ice stream itself and the proximal regions of the northern and southern shear margins. For track $1 \mathrm{~A}$ (Fig. 6a), this statement holds in principle, but spatial variability is much higher than farther up-glacier. Track $1 \mathrm{~A}$ pointed at locations near the ice front (note that the correct location is that of the left plotted track) in an area affected by heavy calving in 2005. The track differences seen are from L3B (February 2005) to L3E (February 2006) and L3C (May 2005) to L3E (February 2006), during which the north ice stream retreated. The time interval between L3I (October 2007) and L3H (March 2007) appears to be an outlier of exceptionally high change rates in the interior of the ice stream. This is further investigated below. 


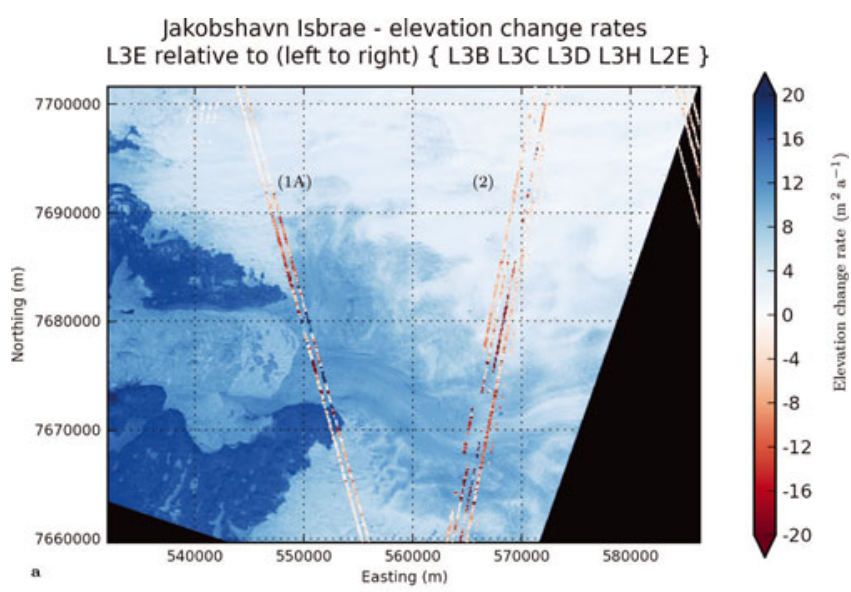

Jakobshavn Isbrae - elevation change rates L3H relative to (left to right) \{ L2B L3D L3E L3I L3J \}

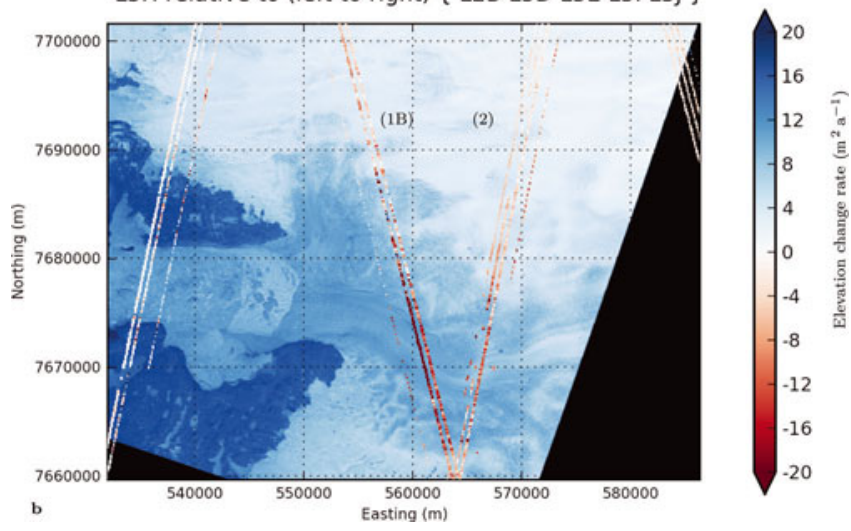

Fig. 6. Jakobshavn Isbræ surface elevation change per year. Elevation change per year is calculated by subtracting elevations from two overlapping tracks and dividing by time (months/12), for all mission pairs possible that include L3H or L3E. (a) Relative to March 2006 (GLAS L3E): differences per year are formed for $L 3 E-\{L 3 B, L 3 C$, L3D, L3H, L2E . Track 1A near calving front (difference pairs are L3E $-\{$ L3B, L3C $\})$, track 2 crosses near bend in south Isbræ. (b) Relative to March 2007 (GLAS L3H): differences per year are formed for $\mathrm{L} 3 \mathrm{H}-$ $\{$ L2B, L3D, L3E, L3I, L3J $\}$. Track 1B and track 2 cross near bend in south Isbræ. (a, b) Results are offset to the right for visualization purposes. Actual location of GLAS ground tracks coincides with the location of the leftmost track in each set, and with the tracks in Figure 5 (note that not all five differences exist in each location; for details, see Figs 8-11). Background ASTER data May 2003, NASA Terra satellite.

The corresponding change rates have been calculated for generalized ice surface roughness measured by the parameter pond $_{\text {res, }}$ shown in map view in Figure 7. As seen in Figure 7, surface roughness change rates are close to zero for any pair of tracks in the interior of the south ice stream (tracks $1 \mathrm{~B}$ and 2). Exceptions are a few isolated locations at the northern shear margin in track 1B (Fig. 7b), which may be attributable to changes in the location of individual large crevasses, possibly caused by the drawdown of the central ice stream relative to the margin. These results are in principle the same as those derived for the 2006-2007 comparison in Section 9. The track that crosses near the calving front (track 1A, Fig. 7a) shows roughness changes locally in the area where the north ice stream retreated in 2005, according to field observations of the first author. In this area, Jakobshavn Isbræ was not a connected, crevassed ice stream any more, but a semi-connected melange of crevassed ice pieces where the calving front had become a transitional area between ice stream and fjord with large icebergs.
Jakobshavn Isbrae - pondres change rates L3E relative to (left to right) \{ L3B L3C L3D L3H L2E \}

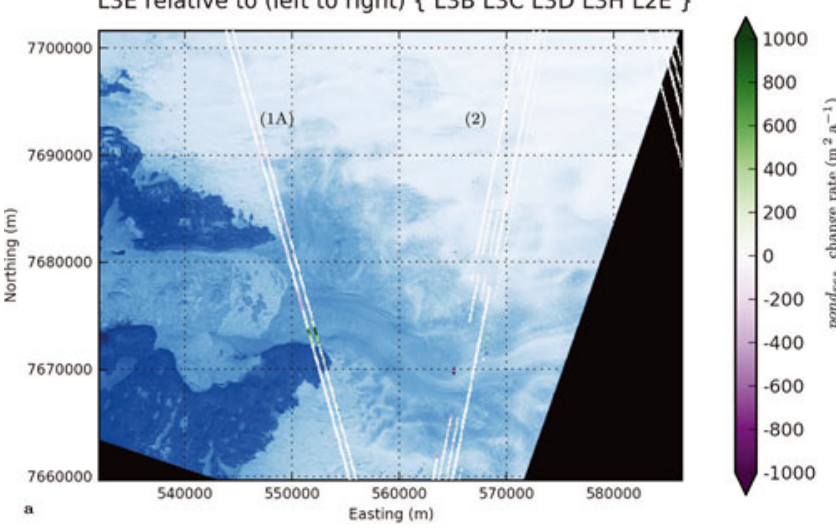

Jakobshavn Isbrae - pondres change rates L3H relative to (left to right) $\{$ L2B L3D L3E L3I L3J $\}$

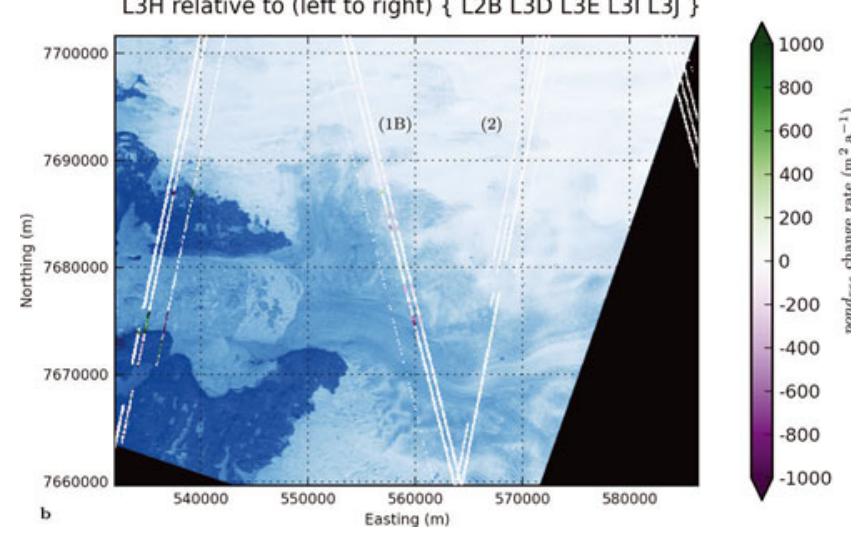

Fig. 7. Jakobshavn Isbræ surface roughness change per year. Surface roughness change per year is calculated by subtracting surface roughness values $\left(\right.$ pond $_{\text {res }}$ ) from two overlapping tracks and dividing by time (months/12), for all mission pairs possible that include L3E or L3H. (a) Relative to March 2006 (GLAS L3E): differences per year are formed for $\mathrm{L} 3 \mathrm{E}-\{\mathrm{L} 3 \mathrm{~B}, \mathrm{~L} 3 \mathrm{C}, \mathrm{L} 3 \mathrm{D}, \mathrm{L} 3 \mathrm{H}, \mathrm{L} 2 \mathrm{E}\}$. Track $1 \mathrm{~A}$ near calving front (difference pairs are $L 3 E-\{L 3 B, L 3 C\}$ ), track 2 crosses near bend in south Isbræ. (b) Relative to March 2007 (GLAS L3H): differences per year are formed for $L 3 H-\{L 2 B, L 3 D, L 3 E, L 3 I, L 3 J\}$. Track $1 \mathrm{~B}$ and track 2 cross near the bend in south Isbræ. $(\mathrm{a}, \mathrm{b})$ Results are offset to the right for visualization purposes. Actual location of GLAS ground tracks coincides with the location of the leftmost track in each set, also with the tracks in Figure 5 (note that not all five differences exist in each location; for details, see Figs 8-11). Background ASTER data May 2003, NASA Terra satellite.

Elevation and roughness changes are investigated in more detail using values plotted along tracks in Figures 8-11. Elevation changes (Figs 8a, 9a, 10a and 11a) are plotted such that a continued surface lowering through time is pictured by a drop in elevation from one panel to the next. The top panel for each figure shows the elevation profile that follows the tracks and hence runs approximately across-flow for the ice stream. Note that there are fewer roughnessdifference values than elevation-difference values, because roughness is calculated for a moving window. Running means of elevation and roughness values over $1000 \mathrm{~m}$ along-track windows are calculated for every $100 \mathrm{~m}$ alongtrack (red in Figs 8-11).

From front up-glacier:

Track 1A crosses near the front of both the north and south ice streams. Only the earliest pairs have data differences (the front retreated later beyond this area). The inner margin, where north and south ice streams 

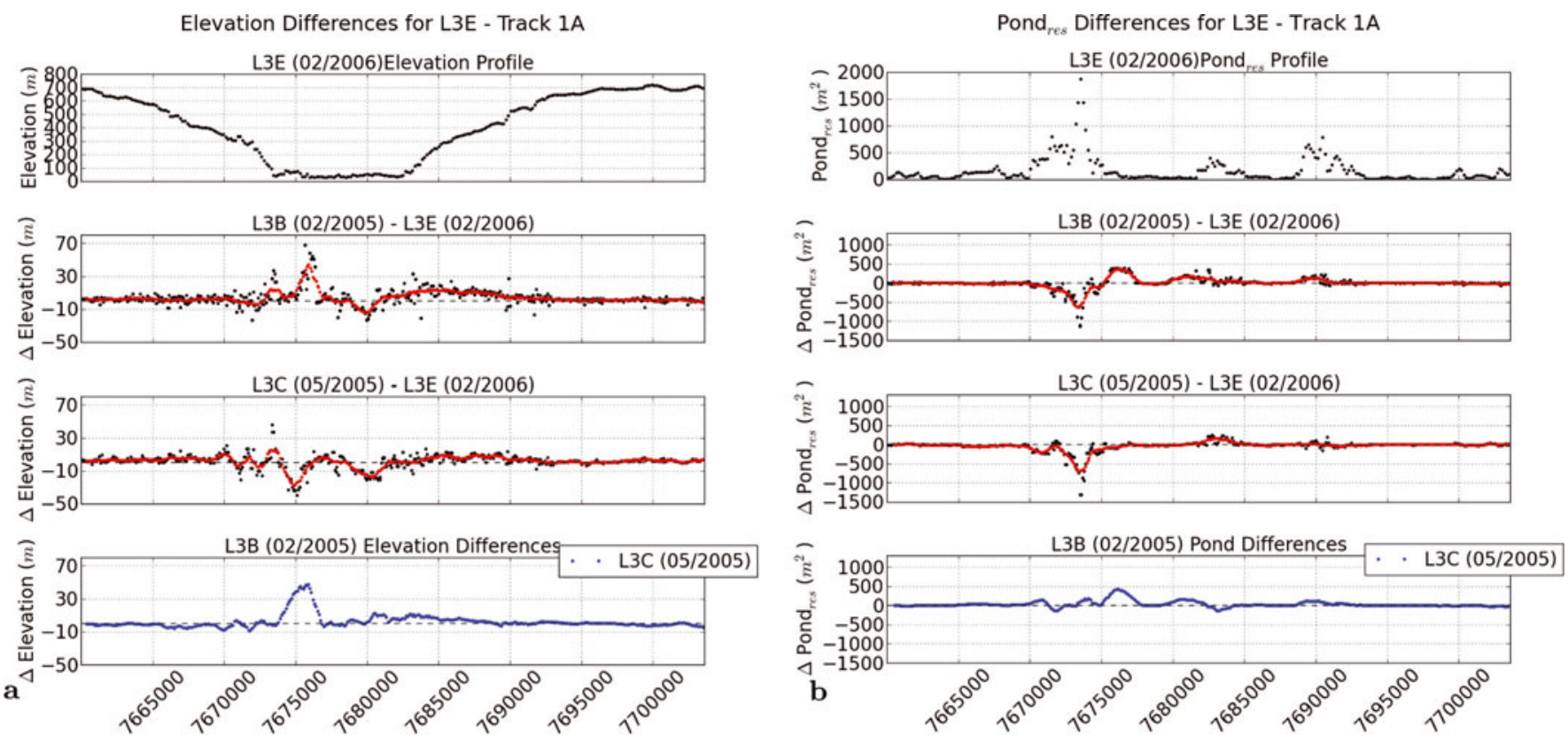

Fig. 8. Jakobshavn Isbræ surface elevation and roughness changes. Surface roughness changes are calculated as differences in parameter pond $_{\text {res. }}$ (a) Surface elevation profile and elevation differences for L3E - track $1 \mathrm{~A}$. (b) Surface roughness profile and roughness differences for L3E - track 1A. In (a, b), middle two panels, black dots show differences from pairs of measurements, and red dots show differences of running means of measurements (where means are calculated over $1000 \mathrm{~m}$ windows for every $100 \mathrm{~m}$ along-track). Bottom panels show elevation and pond $_{\text {res }}$ differences, formed by subtracting $1000 \mathrm{~m}$ running means (L3C $\left.-\mathrm{L} 3 \mathrm{~B}\right)$.

converge, is near N 7677000. Elevation loss was largest over the south ice stream. The elevation loss in the north ice stream extends up into the entire crevassed region and along the margin of the north ice stream (to $\mathrm{N}$ 7690000). The pond ${ }_{\text {res }}$ difference plots show that roughness variability is highest along the shear margins and the inner confluence of the north and south ice streams, which is explained by crevassing. The laser signal can hit the bottoms of crevasses, which change their location rapidly. Notably, the area of elevation loss extends across the entire north and south ice streams, except for a thickening at N 7680000 in February 2005February 2006 that is not present in the May 2005February 2006 difference. Roughness changes do not follow the trend of elevation changes, and overall roughness changes are very low.

Track 1B crosses just upstream of the so-called 'rumple' (Echelmeyer and others, 1991), an area of heavy crevassing upstream of the confluence of the north and south ice streams. Elevation is lowest (for L3H in March 2007) immediately north of the south ice stream. Figure 10a shows that surface lowering at this crossing is much higher over the south ice stream than over the north ice stream. Surface lowering extends into the southern shear margin of the south ice stream, but is not as strong as over the main fast-moving provinces (boundary at $\sim N 7670000$ ). Elevation loss was $40-60 \mathrm{~m}$ from L2B (February 2004) to L3H (March 2007), 20-30 m between L3H (March 2007) and L3J (October 2007), and only 15-20 m between L3H (March 2007) and L3J (March 2008). Hence a small elevation increase must have occurred between October 2007 and March 2008 in the south ice stream, which indicates thickening in winter.

North of $\mathrm{N} 7680000$, track 1B crosses only several shear zones east of the north ice stream, not the north ice stream itself. Elevation losses are much lower than for the south and north ice streams (Fig. 8) and vary locally.

The most interesting track is track $\mathbf{2}$, which traverses the upper Jakobshavn Isbræ south ice stream near the turn in direction (Figs 9 and 11) (note that the leftmost changerate track indicates the correct location of a GLAS track). The following landmarks or boundaries of glaciological provinces are: $\mathrm{N} 7663000$ - southern boundary of southern shear margin of south ice stream; N 7667000 - southern shear margin of south ice stream/south ice stream; N 7668000-7669000 - center of south ice stream; N 7673000 - south ice stream/northern shear margin of south ice stream; N 7678000 - northern boundary of northern shear margin of south ice stream.

The series of plots of difference values demonstrates that $\mathrm{L} 3 \mathrm{H}-\mathrm{L} 3 \mathrm{E}$ is the best data pair (used in Sections 8 and 9). The values over the south ice stream are intermittent, but indicate that surface lowering continues throughout the observation time frame, as indicated in the bottom panels of Figures 9 and 11. Between L3B (February 2005) and L3E (February 2006), surface lowering over the central ice stream was $15-20 \mathrm{~m}, \sim 30 \mathrm{~m}$ between $\mathrm{L} 3 \mathrm{~B}$ and L3H (March 2007) and 40-60 m between L3B (February 2005) and L2E (March 2009), an average of 10-15 $\mathrm{m} \mathrm{a}^{-1}$, varying locally. The area north of the ice stream also lost elevation, $\sim 10 \mathrm{~m}$ in 4 years $\left(2.5 \mathrm{~m} \mathrm{a}^{-1}\right.$; Fig. 9). An exception to the general surface lowering over the ice stream is a thickening in winter between October 2005 and February 2006 (Fig. 11), which repeated in 2007/08, as noted above, and corresponds to a slowing of the flow velocity reported in Joughin and others (2012). Thickening is limited to the ice stream itself, while the area north of the ice stream lost elevation during the same winter.

Roughness change over the same time frames is again insignificant and does not show a trend over time. 
Elevation Differences for L3E - Track 2

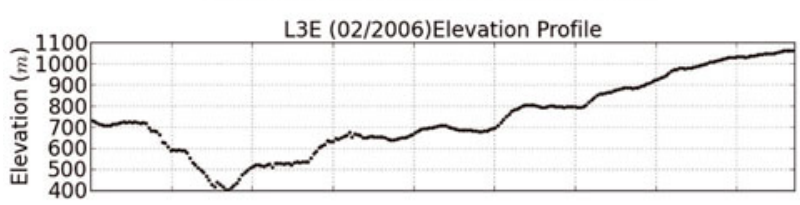

L3B $(02 / 2005)-$ L3E $(02 / 2006)$
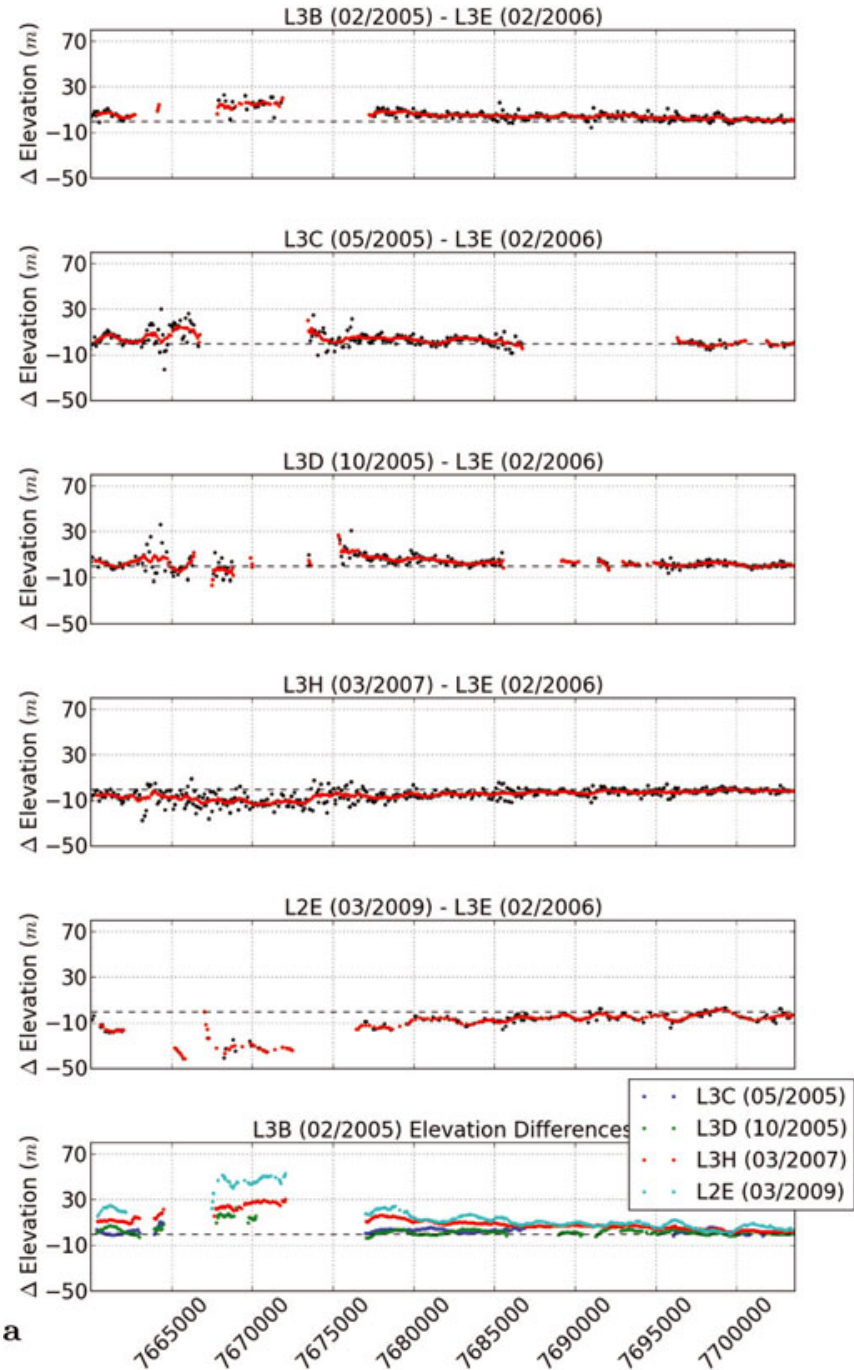

Pond $_{\text {res }}$ Differences for L3E - Track 2
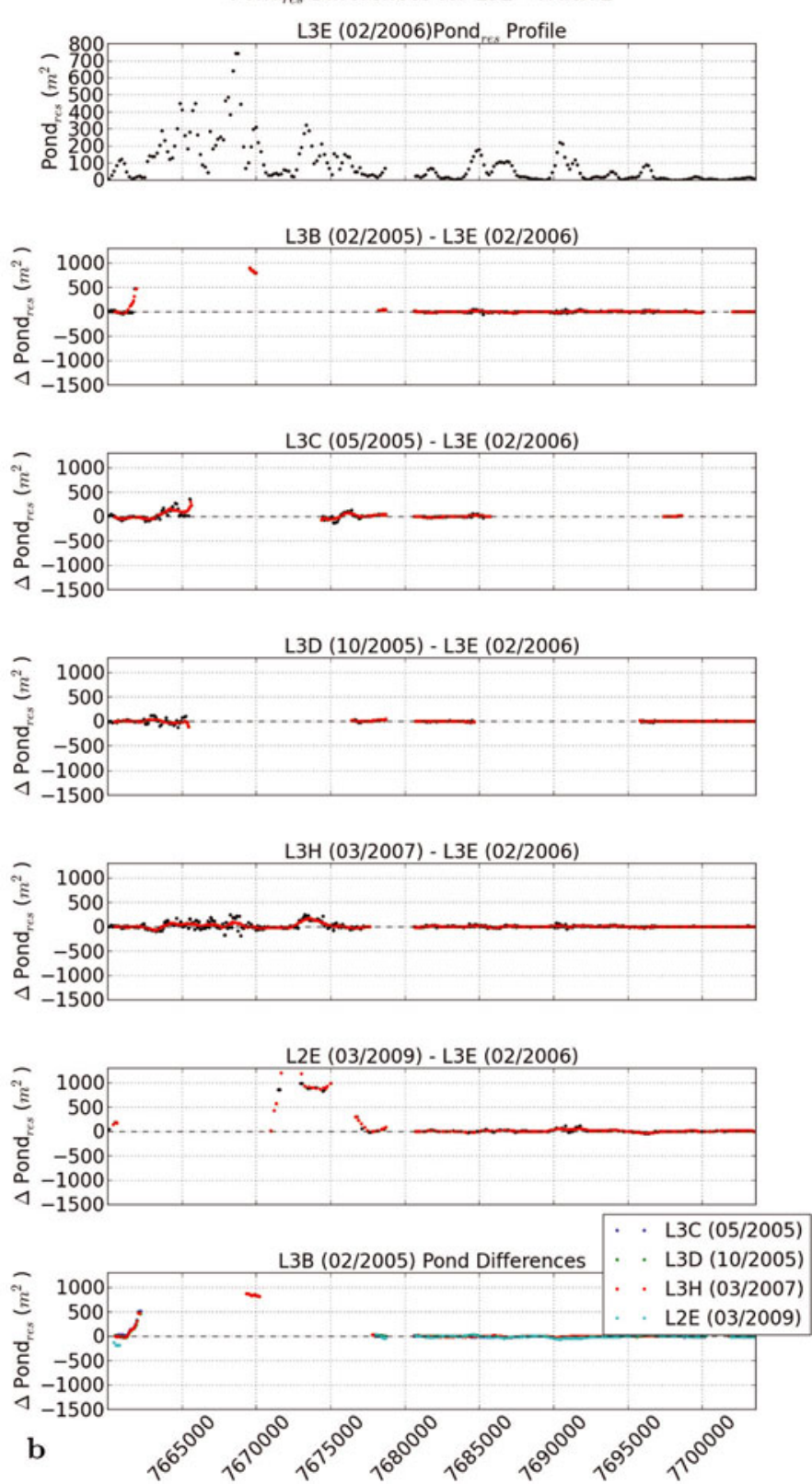

Fig. 9. Jakobshavn Isbræ surface elevation and roughness changes. Surface roughness changes are calculated as differences in parameter pond $_{\text {res. }}$ (a) Surface elevation profile and elevation differences for L3E - track 2. (b) Surface roughness profile and roughness differences for L3E - track 2. In (a, b), second to second-to-last panels, black dots show differences from pairs of measurements, and red dots show differences of running means of measurements (where means are calculated over $1000 \mathrm{~m}$ windows for every $100 \mathrm{~m}$ along-track). Bottom panels show elevation and pond $_{\text {res }}$ differences through time 2005-2009, formed by subtracting 1000 m running means (L3C, L3D, L3H, L2E - L3B).

Largest variabilities in roughness occur over the shear margins. Figure 11 indicates essentially the same process of surface lowering and a lack of roughness change, for the years 2004-08. Surface lowering is $40-60 \mathrm{~m}$ in 4 years, and $10-15 \mathrm{ma}^{-1}$.

In summary, the detailed analysis has provided more accurate values on spatial and temporal variability of elevation change, which is $10-15 \mathrm{~m} \mathrm{a}^{-1}$ over the south ice stream, and indicated a winter thickening. Roughness shows a variability in the shear margins, but did not change during the period of drastic surface lowering. A comparison of roughness and elevation change comes qualitatively to the same result for the analysis of time series as for the analysis of the pair of $\mathrm{L} 3 \mathrm{H}-\mathrm{L} 3 \mathrm{E}$ datasets.

\section{SUMMARY OF RESULTS AND \\ INTERPRETATION: ATTRIBUTION OF CHANGES DURING RAPID RETREAT OF JAKOBSHAVN ISBRA}

The analyses in the previous sections led to the following results:

1. For glaciers and ice streams generalized spatial surface roughness (at scales larger than $10 \mathrm{~m}$ ) is an indicator of ice dynamics.

2. Surface roughness may be quantified by the $p o n d_{\mathrm{var}}$ and pond $_{\text {res }}$ parameters as derived from ICESat GLAS and

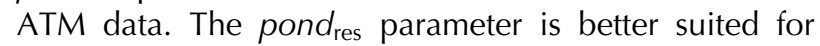
analysis of ice-stream regions because of local slopes in surface elevation. 
Elevation Differences for L3H - Track 1B L3H (03/2007)Elevation Profile

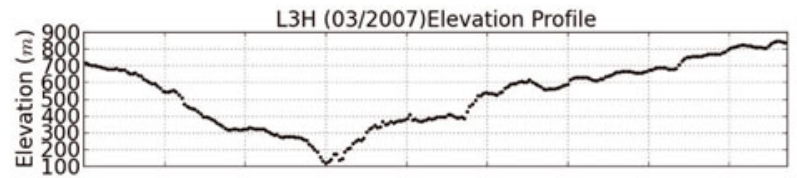

L2B (02/2004) - L3H (03/2007)

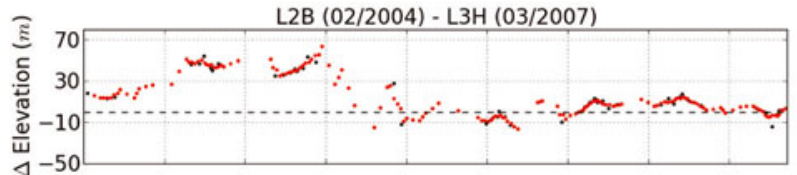

L3I (10/2007) - L3H (03/2007)

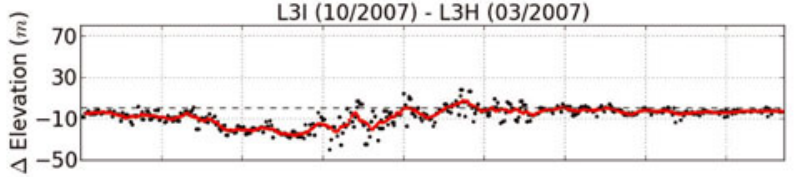

L3] $(03 / 2008)$ - L3H (03/2007)
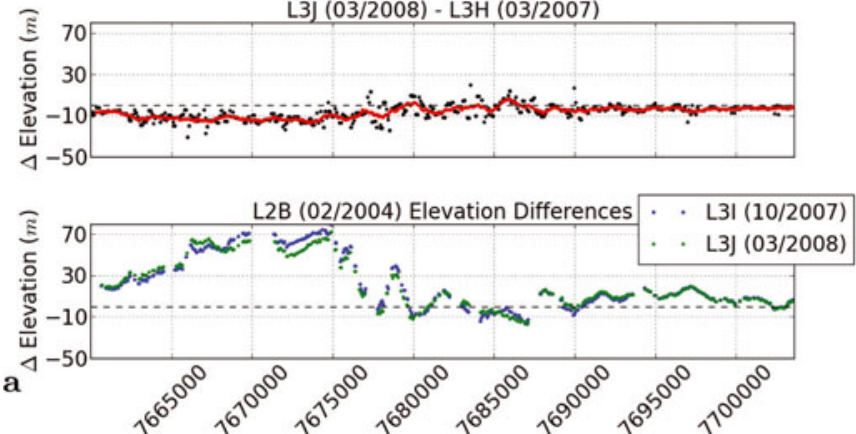

Pond $_{r e s}$ Differences for L3H - Track 1B L3H (03/2007)Pond ${ }_{\text {res }}$ Profile

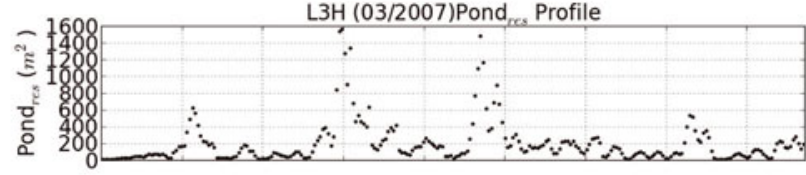

L2B $(02 / 2004)-$ L3H (03/2007)
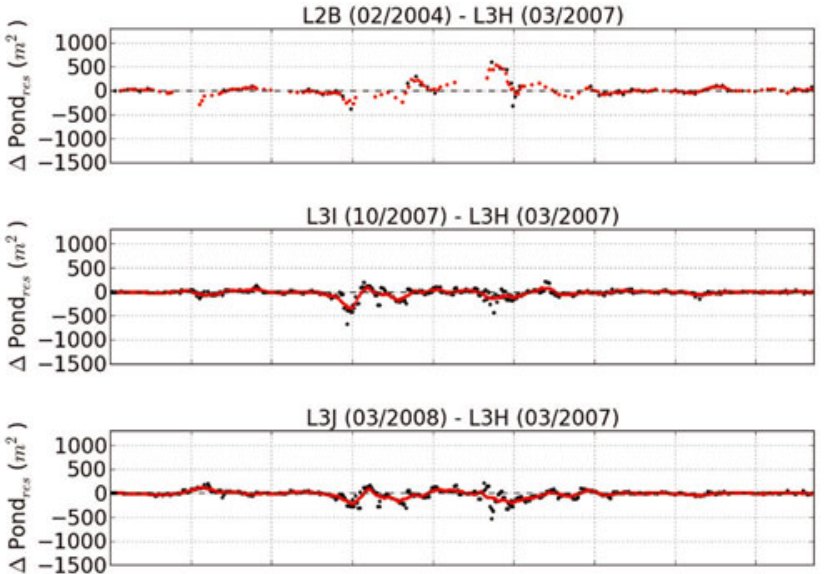$$
1500+100
$$

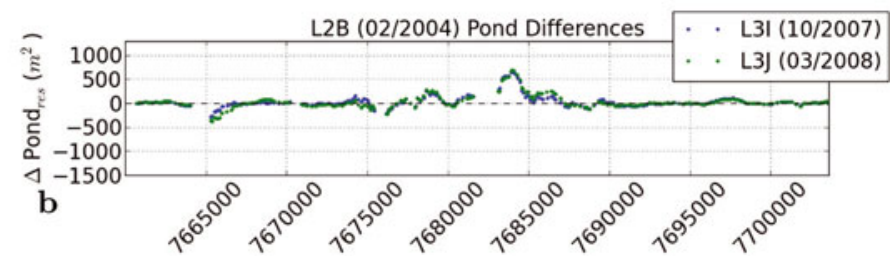

Fig. 10. Jakobshavn Isbræ surface elevation and roughness changes. Surface roughness changes are calculated as differences in parameter pond $_{\text {res. }}$ (a) Surface elevation profile and elevation differences for $\mathrm{L} 3 \mathrm{H}$ - track 1B. (b) Surface roughness profile and roughness differences for $\mathrm{L} 3 \mathrm{H}$ - track 1B. In (a, b), second to second-to-last panels, black dots show differences from pairs of measurements, and red dots show differences of running means of measurements (where means are calculated over $1000 \mathrm{~m}$ windows for every $100 \mathrm{~m}$ along-track). Bottom

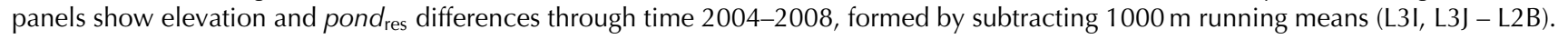

3. Surface lowering is largest over the south ice stream, above the center of the trough.

4. While surface elevation decreased by $\sim 10-15 \mathrm{ma}^{-1}$ between 2004 and 2009, surface roughness remained almost unchanged.

5. Spatial acceleration is caused by the existence of a subglacial trough. The trough in the bedrock morphology leads to a convergence of flow, concentration of ice in the trough and faster flow due to surface slope in the longitudinal direction of the trough. These processes lead to a spatial sequence of crevasse provinces arranged in the transverse direction.

We now use the above results to investigate what may have caused the observed acceleration in Jakobshavn Isbræ. Possible causes include: (i) an internal dynamic change in the glacier system, such as a kinematic wave, (ii) a climatically caused acceleration in the upstream glacier system (faster flow following warming of ice), (iii) front retreat as part of a fjord-glacier cycle (Clarke, 1987; Meier and Post, 1987), (iv) front retreat because of fjord-water warming (Holland and others, 2008; Rignot and others, 2012; Straneo and others, 2012), and (v) increased basal sliding due to increased water at the base of the glacier (cf. Greve, 2005; Greve and Blatter, 2009; Herzfeld and others, 2012).

Both (i) and (ii) involve dynamic changes in the interior of the glacier, whereas (iii) and (iv) are initiated at the calving front. We analyze which of the possible causes are consistent with our results.

The detailed spatio-temporal analysis, based on all pairs of ICESat GLAS datasets with matching points, has provided accurate values on spatial and temporal variability of elevation change and roughness change. Overall, elevation change was $\sim 10-15 \mathrm{ma}^{-1}$ surface lowering over the southern branch of Jakobshavn Isbræ, with an indication of some winter thickening. The time series analysis showed that this surface change pattern persisted between 2004 and 2009 over the south ice stream.

Roughness parameters such as pond $d_{\text {var }}$ and pond $d_{\text {res }}$ provide a proxy mapping of structural glaciological provinces, due to the effects of crevasse types or crevassing intensity, and hence dynamic provinces. Since roughness did not change, we conclude that the distribution of the dynamic provinces remained essentially the same. The dynamic provinces are largely caused by the several glaciological effects on ice flow associated with movement of ice into and down the subglacial trough (in the area around the location of the GLAS track, which is $\sim 15 \mathrm{~km}$ from the 2003 calving front). Given the combined observations of acceleration of glacier flow and significant surface lowering, but no detected changes in roughness as measured by our parametric approach, an internal dynamic change in the glacier system is not likely a cause for the surface lowering, front retreat or acceleration, as this would result in a change in roughness provinces in the central ice stream. 
Elevation Differences for L3H - Track 2

L3H (03/2007)Elevation Profile

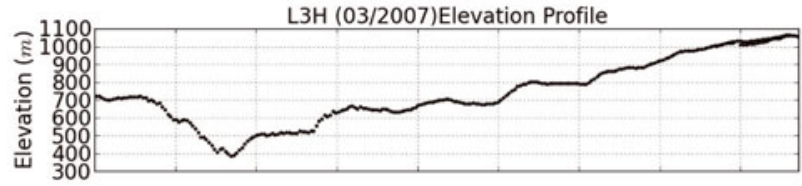

L2B (02/2004) - L3H (03/2007)
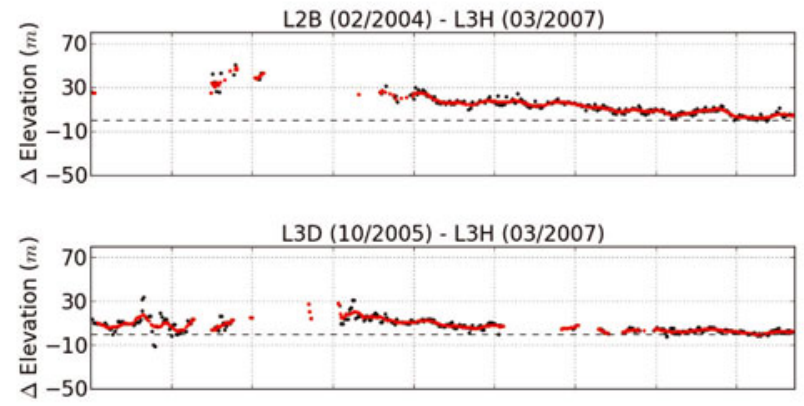

L3E (02/2006) - L3H (03/2007)
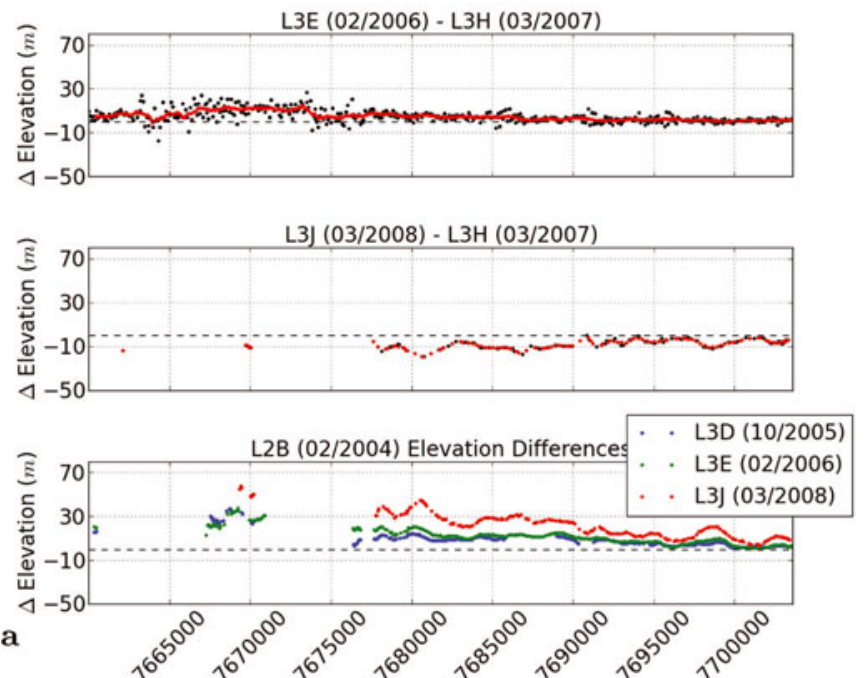

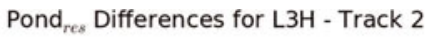
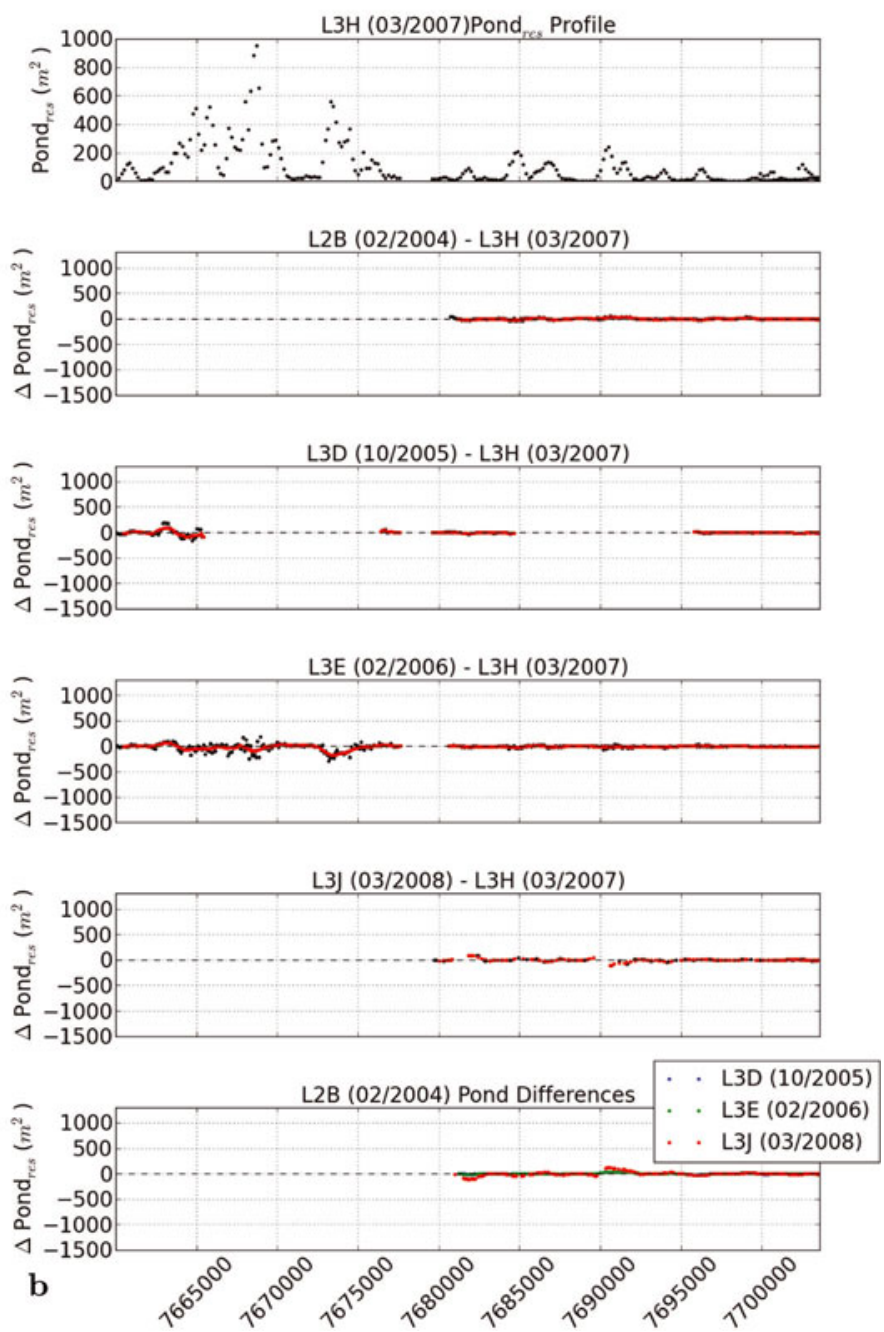

Fig. 11. Jakobshavn Isbræ surface elevation and roughness changes. Surface roughness changes are calculated as differences in parameter

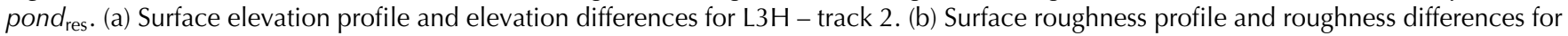
L3H - track 2. In (a, b), second to fourth panels, black dots show differences from pairs of measurements, and red dots show differences of running means of measurements (where means are calculated over $1000 \mathrm{~m}$ windows for every $100 \mathrm{~m}$ along-track). Bottom panels show elevation and pond $_{\text {res }}$ differences through time 2004-2008, formed by subtracting 1000 m running means (L3D, L3E, L3J - L2B).

At this point we take an excursion to ascertain the validity of the conclusion relating change in roughness, measured by the pond parameter, and change in crevasse types, as a means to rule out an internal dynamic change in the glacier system. An internal dynamic change would result in new gradients in the kinematic forces that cause crevassing. The simplest, first case is that crevassing affects previously uncrevassed ice; in this case, spatial variability in an image or altimeter dataset increases and hence the pond parameter increases. A second case is that a new force affects previously crevassed ice; the new force field is not linearly dependent on the existing force field; new crevasses form, overprinting the existing crevasse fields; spatial variability increases and hence the pond parameter increases. The remaining, third case is that a new force affects previously crevassed ice and the new force field is linearly dependent on the existing force field; this is the case of a simple acceleration in the same direction as the existing flow, which for a previously crevassed fast-flowing glacier may (or may not) change the spacing of crevasses; in this case the pond parameter remains the same (because the pond parameter is defined as the maximal value for all distance classes in the vario function or residual vario function). The third case is the situation for Jakobshavn Isbræ. For examples illustrating changes in surface crevasse types caused by changes in the kinematic forces during a glacier surge, the reader is referred to Mayer and Herzfeld (2000) and Herzfeld (1998). The argument in this section holds more generally than for surges, namely for any sequences of kinematic forces that cause or change crevassing.

The interpretation - that an internal dynamic change in the glacier system is not (or not likely) a cause for the surface lowering, front retreat or acceleration - does not contradict the changes observed near the calving front of Jakobshavn Isbræ during rapid retreat (for a description of the structural changes during retreat see Mayer and Herzfeld, 2008). Instead, the results of the analyses support the hypothesis of a climatically induced surface lowering and are consistent with a front retreat as part of a fjord-glacier cycle or following warming of fjord water, as described by Holland and others (2008), Rignot and others (2012) and Straneo and others (2012). Increasing temperatures over the Greenland ice sheet as observed by Box and Steffen (2001), Steffen and Box (2001) and Box and others (2009) have also been considered 


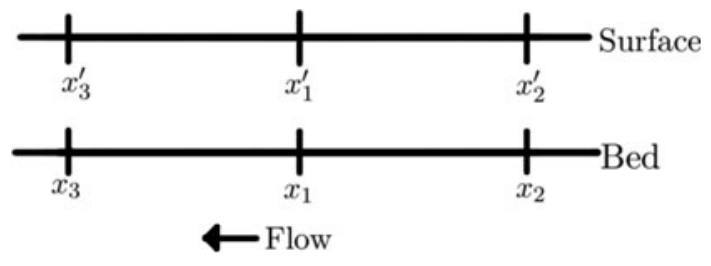

Fig. 12. Sketch for discussion of basal water and crevasse zones.

a likely cause for surface lowering in the Jakobshavn region, but this signal may not be strong enough to cause the observed acceleration. Results of our analysis of the tracks that cross the interior of the south ice stream are consistent with both increasing temperatures and warming fjord water as initiators of acceleration. The fact that surface roughness of the track near the calving front changes over time suggests an initiation of the acceleration processes near the front and therefore favors the ice-ocean-interaction line of thought.

The observations and analyses are also consistent with the hypothesis of a front retreat that triggers a disintegration of the glacier near the front, which propagates up-glacier due to lack of back-holding force to the area of the confluence of the north and south ice streams and causes further acceleration in the ice stream. The classic glaciological explanation of the sudden retreat of a fjord glacier lies in the fjord-glacier cycle, according to which a fjord glacier retreats over a long time, until it reaches a minimal extent and then advances again (cf. Clarke, 1987; Meier and Post, 1987; Pfeffer, 2007; Vieli and Nick, 2011). The duration of a fjord cycle is typically on the order of $1 \mathrm{ka}$. This possibility is supported by the observations that Jakovshavn Isbræ has been retreating slowly throughout recent decades, experienced rapid retreat between 1999 and 2007 and then came to a halt in 2007, as the front reached the confluence of the north and south ice streams, which was considered a possible natural limit for retreat. However, the glacier has meanwhile retreated beyond this line. Recent research indicates that warming of the fjord water that interacts with the floating tongue of the glacier may cause rapid retreat as observed at Jakobshavn Isbræ (Holland and others, 2008; Rignot and others, 2012; Straneo and others, 2012). A number of explanations of physical processes that may have caused the retreat and acceleration have been examined in Joughin and others (2012), using models. This paper demonstrates how characterization of spatial surface roughness can be derived from satellite and airborne laser altimeter data and applied to narrow down possible physical processes.

\section{Discussion of relationships between increased basal water pressure, basal sliding, roughness change and acceleration (cause (e))}

As is well known, increased water pressure at the bed of a glacier reduces friction and hence increases basal sliding, which in turn causes an acceleration in the glacier (Cuffey and Paterson, 2010). The effect of the bed-topographic trough on water at the bed and acceleration has been analyzed in Herzfeld and others (2012) for Jakobshavn Isbræ.

We conduct a thought experiment to determine the possible relative locations of increase in basal water, acceleration and change in crevasse type, and hence generalized roughness, along-flow in a glacier.

Consider locations $x_{i}$ at the bed and $x_{i}{ }^{\prime}$ at the surface near $x_{i}$ (a little upstream), with a given location $x_{1}$, a location $x_{2}$ upstream of $x_{1}$ and a location $x_{3}$ downstream of $x_{1}$, as sketched in Figure 12.

Extra water at the bed, or more specifically a higher subglacial water pressure, at $x_{1}$, will cause a reduced basal shear stress and therefore an acceleration of the ice in the region near $x_{1}, x_{1}{ }^{\prime}$. This acceleration effect will propagate upstream (schematically to $x_{2}, x_{2}{ }^{\prime}$ ) because of lack of back-holding force at $x_{1}, x_{1}{ }^{\prime}$. The extra water tends to flow downhill at the bed (to $x_{3}, x_{3}{ }^{\prime}$ ), unless there are obstructions, which causes acceleration downstream. If the ice at $x_{3}{ }^{\prime}$ did not accelerate, then the glacier would form a bulge. The situation would be similar to that of a surge-type glacier, where a bulge forms and the hydrologic system is obstructed (Kamb, 1987; Herzfeld and others, 2013a). Changes in the crevasse provinces would ensue, due to compressional forces during bulge formation and extensional forces during collapse (Herzfeld and others, 2013b). We do not see any changes in the crevasse provinces, as indicated by overall roughness. Hence any extra water flows downhill and the entire lower glacier accelerates. (Note that the specific hydrologic processes do not need to be known and cannot be inferred.) The only remaining possibility is that point $x_{1}$, the location of extra water, is already at or near the front, or $x_{1}$ is not a point but the region of the entire lower glacier. This makes sense, because (i) extra water may come from extra melting, which is higher at lower elevation (temperature gradient with altitude), (ii) simulations with ice-dynamic models UMISM (Fastook, 1993; Fastook and Prentice, 1994) and SICOPOLIS (Greve, 1995, 1997) show more basal water at lower elevations (Herzfeld and others, 2012), due to temperature and pressure, and (iii) warming water in the fjord would also initiate melting near the calving front (Holland and others, 2008; Rignot and others, 2012; Straneo and others, 2012).

In conclusion, our analyses are consistent with either (1) no change in the hydrological system, or (2) additional basal water and increased basal sliding downstream of a source, or (3) increased water in a region near the front or extending upward from the front. The roughness analysis does not directly show the location of changes in basal water, but may be used to rule out certain situations of changes in the hydrologic system.

In general, mapping of roughness provinces from satellite observations provides a means to put observations near the front of the glacier into a geographically and geophysically larger context and thus aids in synoptic studies of many parameters in a complex system of processes.

\section{OUTLOOK TO ICESat-2}

Time-dependent analysis of the roughness characteristics in the along-flow direction of the ice stream is expected to reveal changes; however, the limited spatial coverage by GLAS data does not allow such investigations. As a consequence of the higher resolution of the ATM data compared to GLAS data, application of the pond parameter resolves the across-track sequence of dynamic provinces much better. Future satellite ICESat-2, to be launched by NASA in 2016, will carry a micro-pulse photon-counting altimeter with six beams in the across-track direction, whose expected resolution is $0.7 \mathrm{~m}$ in the along-track direction (Abdalati and others, 2008, 2010; Herzfeld and others, 2014). Spatially and temporally well-resolved observation of ice-surface elevation and elevation change, especially in the highly dynamic regions of the outlet glaciers, has been 
identified as critical for understanding the changes in the Greenland and Antarctic ice sheets, the expected volume loss from the ice sheets, and the impending sea-level rise as a consequence of mass loss. The analyses undertaken here suggest that ICESat-2 data can be used to map glaciodynamic provinces in detail. From the order-of-magnitude better spatial and temporal resolution of future ICESat-2 data, compared to GLAS data, more information can be expected in two ways: (1) simply due to improved mapping capabilities of the sensor, using the same analysis methods as for ICESat data, and (2) through application of multiple parameters (for examples, see Herzfeld, 2008) that capture spacing of crevasses, melt pond distribution, deformation characteristics and other glaciologic variables.

\section{ACKNOWLEDGEMENTS}

Funding through NASA Cryospheric Sciences Award NNX09A083G (principal investigator Ute Herzfeld) 'Spatial Ice Surface Roughness - Scale-Dependent Analyses of Ice Surfaces and Implications for Cryospheric Sciences and Satellite Altimetry (in Particular, for ICESat and ICESat-2)' and the University of Colorado Undergraduate Research Opportunity Program (UROP) is gratefully acknowledged, the latter especially by W.A.Y., P.A.C. and A.W. Thanks are due to Robert Schutz and Tim Urban (University of Texas, Austin, TX, USA) for information on ICESat-mission offtrack-pointing manoeuvres, and to Ralf Greve (Hokkaido University, Sapporo, Japan) and Ted Scambos (US National Snow and Ice Data Center, Boulder, CO, USA) for discussion on some of the topics in the paper.

\section{REFERENCES}

Abdalati W and 26 others (2008) Report of the ad-hoc Science Definition Team for the Ice Cloud and Land Elevation Satellite-II (ICESat-II), November 2008. National Aeronautics and Space Administration (NASA)

Abdalati $W$ and 16 others (2010) The ICESat-2 laser altimetry mission. IEEE Proc., 98(5), 735-751 (doi: 10.1109/JPROC. 2009.2034765)

Box JE and Steffen K (2001) Sublimation on the Greenland ice sheet from automated weather station observations. J. Geophys. Res., 106(D24), 33 965-33 981 (doi: 10.1029/2001JD900219)

Box JE, Yang L, Bromwich DH and Bai L-S (2009) Greenland ice sheet surface air temperature variability: 1840-2007. J. Climate, 22(14), 4029-4049 (doi: 10.1175/2009JCLI2816.1)

Clarke GKC (1987) Fast glacier flow: ice streams, surging and tidewater glaciers. J. Geophys. Res., 92(B9), 8835-8841 (doi: 10.1029/JB092iB09p08835)

Cuffey KM and Paterson WSB (2010) The physics of glaciers, 4th edn. Butterworth-Heinemann, Oxford

Echelmeyer K and Harrison WD (1990) Jakobshavns Isbræ, West Greenland: seasonal variations in velocity - or lack thereof. J. Glaciol., 36(122), 82-88

Echelmeyer K, Clarke TS and Harrison WD (1991) Surficial glaciology of Jakobshavns Isbræ, West Greenland: Part I. Surface morphology. J. Glaciol., 37(127), 368-382

Echelmeyer K, Harrison WD, Clarke TS and Benson C (1992) Surficial glaciology of Jakobshavns Isbræ, West Greenland: Part II. Ablation, accumulation and temperature. J. Glaciol., 38(128), 169-181

Fastook JL (1993) The finite-element method for solving conservation equations in glaciology. Comp. Sci. Eng., 1(1), 55-67

Fastook JL and Prentice M (1994) A finite-element model of Antarctica: sensitivity test for meteorological mass-balance relationship. J. Glaciol., 40(134), 167-175
Gogineni S and 9 others (2001) Coherent radar ice thickness measurements over the Greenland ice sheet. J. Geophys. Res., 106(D24), 33 761-33 772 (doi: 10.1029/2001JD900183)

Greve R (1995) Thermomechanisches Verhalten polythermer Eisschilde - Theorie, Analytik, Numerik. (PhD thesis, Technische Hochschule Darmstadt)

Greve R (1997) Application of a polythermal three-dimensional ice sheet model to the Greenland ice sheet: response to steady-state and transient climate scenarios. J. Climate, 10(5), 901-918 (doi: 10.1175/1520-0442(1997)010<0901:AOAPTD>2.0.CO;2)

Greve R (2003) Kontinuumsmechanik: ein Grundkurs für Ingenieure und Physiker. Springer, Berlin

Greve R (2005) Relation of measured basal temperatures and the spatial distribution of the geothermal heat flux for the Greenland ice sheet. Ann. Glaciol., 42(1), 424-432 (doi: 10.3189/ $172756405781812510)$

Greve R and Blatter H (2009) Dynamics of ice sheets and glaciers. Springer, Dordrecht

Herzfeld UC (1998) The 1993-1995 surge of Bering Glacier (Alaska) - a photographic documentation of crevasse patterns and environmental changes. Trierer Geogr. Stud. 17

Herzfeld UC (2002) Vario functions of higher order - definition and application to characterization of snow surface roughness. Comput. Geosci., 28(5), 641-660 (doi: 10.1016/S0098-3004 (01)00096-6)

Herzfeld UC (2008) Master of the obscure - automated geostatistical classification in presence of complex geophysical processes. Math. Geosci., 40(5), 587-618 (doi: 10.1007/ s11004-008-9174-4)

Herzfeld UC and Mayer H (1997) Surge of Bering Glacier and Bagley Ice Field, Alaska: an update to August 1995 and an interpretation of brittle-deformation patterns. J. Glaciol., 43(145), 427-434

Herzfeld UC and Zahner O (2001) A connectionist-geostatistical approach to automated image classification, applied to the analysis of crevasse patterns in surging ice. Comput. Geosci., 27(5), 499-512 (doi: 10.1016/S0098-3004(00)00089-3)

Herzfeld UC, Mayer H, Feller W and Mimler M (1999) Glacier roughness surveys of Jakobshavns Isbrae drainage basin, West Greenland, and morphological characterization. Z. Gletscherkd. Glazialgeol., 35(2), 117-146

Herzfeld UC, Mayer H, Feller W and Mimler M (2000) Geostatistical analysis of glacier-roughness data. Ann. Glaciol., 30, 235-242 (doi: 10.3189/172756400781820769)

Herzfeld UC, Clarke GKC, Mayer H and Greve R (2004) Derivation of deformation characteristics in fast-moving glaciers. Comput. Geosci., 30(3), 291-302 (doi: 10.1016/j.cageo.2003.10.012)

Herzfeld UC, McBride PJ, Zwally HJ and DiMarzio J (2008) Elevation changes in Pine Island Glacier, Walgreen Coast, Antarctica, based on GLAS (2003) and ERS-1 (1995) altimeter data analyses and glaciological implications. Int. J. Remote Sens., 29(19), 5533-5553 (doi: 10.1080/01431160802020510)

Herzfeld UC, Fastook J, Greve R, McDonald B, Wallin BF and Chen PA (2012) On the influence of Greenland outlet glacier bed topography on results from dynamic ice-sheet models. Ann. Glaciol., 53(60 Pt 2), 281-293 (doi: 10.3189/2012AoG60A061)

Herzfeld UC, McDonald B, Stachura M, Griffin Hale R, Chen P and Trantow T (2013a) Bering Glacier surge 2011: analysis of laser altimeter data. Ann. Glaciol., 54(63 Pt 1), 158-170 (doi: 10.3189/2013AoG63A348)

Herzfeld UC, McDonald B and Weltman A (2013b) Bering Glacier and Bagley Ice Valley surge 2011: crevasse classification as an approach to map deformation stages and surge progression. Ann. Glaciol., 54(63 Pt 2), 279-286 (doi: 10.3189/ 2013AoG63A338)

Herzfeld UC and 6 others (2014) Algorithm for detection of ground and canopy cover in micropulse photon-counting lidar altimeter data in preparation for the ICESat-2 Mission. IEEE Trans. Geosci. Remote Sens., 52(4), 2109-2125 (doi: 10.1109/ TGRS.2013.2258350) 
Holland DM, Thomas RH, de Young B, Ribergaard MH and Lyberth B (2008) Acceleration of Jakobshavn Isbræ triggered by warm subsurface ocean waters. Nature Geosci., 1(10), 659-664 (doi: 10.1038/ngeo316)

Iken A, Echelmeyer K, Harrison W and Funk M (1993) Mechanisms of fast flow in Jakobshavns Isbræ, West Greenland: Part I. Measurements of temperature and water level in deep boreholes. J. Glaciol., 39(131), 15-25

Johnson JV, Prescott PR and Hughes TJ (2004) Ice dynamics preceding catastrophic disintegration of the floating part of Jakobshavn Isbræ, Greenland. J. Glaciol., 50(171), 492-504 (doi: 10.3189/172756504781829729)

Joughin I, Abdalati W and Fahnestock MA (2004) Large fluctuations in speed on Greenland's Jakobshavn Isbræ glacier. Nature, 432(7017), 608-610 (doi: 10.1038/nature03130)

Joughin I and 7 others (2008) Continued evolution of Jakobshavn Isbræ following its rapid speedup. J. Geophys. Res., 113(F4), F04006 (doi: 10.1029/2008JF001023)

Joughin I, Smith BE, Howat IM, Scambos T and Moon T (2010) Greenland flow variability from ice-sheet-wide velocity mapping. J. Glaciol., 56(197), 415-430 (doi: 10.3189/ $002214310792447734)$

Joughin I and 6 others (2012) Seasonal to decadal scale variations in the surface velocity of Jakobshavn Isbræ, Greenland: observation and model-based analysis. J. Geophys. Res., 117(F2), F02030 (doi: 10.1029/2011JF002110)

Kamb B (1987) Glacier surge mechanism based on linked cavity configuration of the basal water conduit system. J. Geophys. Res., 92(B9), 9083-9100 (doi: 10.1029/JB092iB09p09083)

Krabill WB, Thomas RH, Martin CF, Swift RN and Frederick EB (1995) Accuracy of airborne laser altimetry over the Greenland ice sheet. Int. J. Remote Sens., 16(7), 1211-1222 (doi: 10.1080/ 01431169508954472)

Krabill W and 8 others (1999) Rapid thinning of parts of the southern Greenland ice sheet. Science, 283(5407), 1522-1524 (doi: 10.1126/science.283.5407.1522)

Li J (2009) Mapping of ice sheet deep layers and fast outlet glaciers with multi-channel-high-sensitivity radar. (PhD thesis, University of Kansas)

Liu IS (2002) Continuum mechanics. Springer, Berlin

Lohoefener A (2006) Design and development of a multi-channel radar depth sounder. CReSIS Tech. Rep. 109

Luckman A and Murray T (2005) Seasonal variation in velocity before retreat of Jacobshavn Isbræ, Greenland. Geophys. Res. Lett., 32(8), L08501 (doi: 10.1029/2005GL022519)

Marmo BA and Wilson CJL (1998) Strain localisation and incremental deformation within ice masses, Framnes Mountains, east Antarctica. J. Struct. Geol., 20(2-3), 149-162 (doi: 10.1016/S0191-8141(97)00073-4)

Mayer $\mathrm{H}$ and Herzfeld UC (2000) Structural glaciology of the fastmoving Jakobshavn Isbræ, Greenland, compared to the surging Bering Glacier, Alaska, U.S.A. Ann. Glaciol., 30, 243-249 (doi: 10.3189/172756400781820543)

Mayer H and Herzfeld UC (2001) A structural segmentation, kinematic analysis and dynamic interpretation of Jakobshavns Isbræ, West Greenland. Z. Gletscherkd. Glazialgeol., 37(2), 107-123

Mayer $\mathrm{H}$ and Herzfeld UC (2008) The rapid retreat of Jakobshavns Isbræ, West Greenland: field observations of 2005 and structural analysis of its evolution. Natur. Resour. Res., 17(3), 167-179 (doi: 10.1007/s11053-008-9076-7)

Means WD (1976) Stress and strain: basic concepts of continuum mechanics for geologists. Springer, New York

Meier MF and Post A (1987) Fast tidewater glaciers. J. Geophys. Res., 92(B9), 9051-9058 (doi: 10.1029/ JB092iB09p09051)
Moon T, Joughin I, Smith B and Howat I (2012) 21st-century evolution of Greenland outlet glacier velocities. Science, 336(6081), 576-578 (doi: 10.1126/science.1219985)

Nick FM, Vieli A, Howat IM and Joughin I (2009) Large-scale changes in Greenland outlet glacier dynamics triggered at the terminus. Nature Geosci., 2(2), 110-114 (doi: 10.1038/ngeo394)

Pelto MS, Hughes TJ and Brecher HH (1989) Equilibrium state of Jakobshavns Isbræ, West Greenland. Ann. Glaciol., 12, 127-131

Pfeffer WT (2007) A simple mechanism for irreversible tidewater glacier retreat. J. Geophys. Res., 112(F3), F03S25 (doi: 10.1029/ 2006JF000590)

Podlech S and Weidick A (2004) Correspondence. A catastrophic break-up of the front of Jakobshavn Isbræ, West Greenland, 2002/03. J. Glaciol., 50(168), 153-154 (doi: 10.3189/ $172756504781830231)$

Ramsay JG and Lisle RJ (2000) The techniques of modern structural geology. Vol. 3: Applications of continuum mechanics in structural geology. Academic Press, London

Rignot E, Fenty I, Menemenlis D and Xu Y (2012) Spreading of warm ocean waters around Greenland as a possible cause for glacier acceleration. Ann. Glaciol., 53(60 Pt 2), 257-266 (doi: 10.3189/2012AoG60A136)

Rist MA and 6 others (1999) Experimental and theoretical fracture mechanics applied to Antarctic ice fracture and surface crevassing. J. Geophys. Res., 104(B2), 2973-2987 (doi: 10.1029/1998JB900026)

Schutz BE, Zwally HJ, Shuman CA, Hancock D and DiMarzio JP (2005) Overview of the ICESat Mission. Geophys. Res. Lett., 32(21), L21S01 (doi: 10.1029/2005GL024009)

Spinhirne JD, Palm SP and Hart WD (2005) Antarctica cloud cover for October 2003 from GLAS satellite lidar profiling. Geophys. Res. Lett., 32(22), L22S05 (doi: 10.1029/2005GL023782)

Steffen K and Box J (2001) Surface climatology of the Greenland ice sheet: Greenland Climate Network 1995-1999. J. Geophys. Res., 106(D24), 33 951-33 964 (doi: 10.1029/2001JD900161)

Straneo F and 8 others (2012) Characteristics of ocean waters reaching Greenland's glaciers. Ann. Glaciol., 53(60 Pt 2), 202210 (doi: 10.3189/2012AoG60A059)

Suppe J (1985) Principles of structural geology. Prentice Hall, Englewood Cliffs, NJ

Thomas RH (2004) Force-perturbation analysis of recent thinning and acceleration of Jakobshavn Isbræ, Greenland. J. Glaciol., 50(168), 57-66 (doi: 10.3189/172756504781830321)

Thomas R and 17 others (2004) Accelerated sea-level rise from West Antarctica. Science, 306(5694), 255-258 (doi: 10.1126/ science.1099650)

Truffer $M$ and Echelmeyer KA (2003) Of isbræ and ice streams. Ann. Glaciol., 36, 66-72 (doi: 10.3189/172756403781816347)

Twiss RJ and Moores EM (1992) Structural geology. WH Freeman, New York

Vieli A and Nick FM (2011) Understanding and modelling rapid dynamic changes of tidewater outlet glaciers: issues and implications. Surv. Geophys., 32(4-5), 437-458 (doi: 10.1007/ s10712-011-9132-4)

Vornberger PL and Whillans IM (1990) Crevasse deformation and examples from Ice Stream B, Antarctica. J. Glaciol., 36(122), 3-10

Weidick A (1984) Studies of glacier behaviour and glacier mass balance in Greenland: a review. Geogr. Ann. A, 66(3), 183-195 (doi: 10.2307/520693)

Zwally HJ and 15 others (2002) ICESat's laser measurements of polar ice, atmosphere, ocean and land. J. Geodyn., 34(3-4), 405-445 (doi: 10.1016/S0264-3707(02)00042-X)

Zwally HJ and 7 others (2005) Mass changes of the Greenland and Antarctic ice sheets and shelves and contributions to sea-level rise: 1992-2002. J. Glaciol., 51(175), 509-527 (doi: 10.3189/ 172756505781829007) 